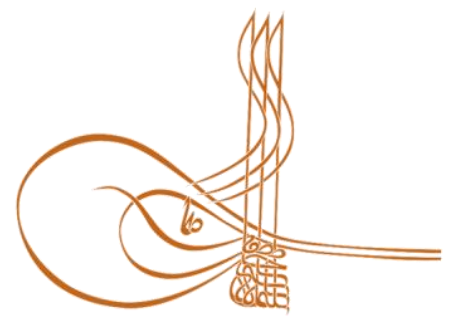

www.turkishstudies.net/economy
Turkish Studies - Economics, Finance, Politics

eISSN: $2667-5625$

Research Article / Araştırma Makalesi

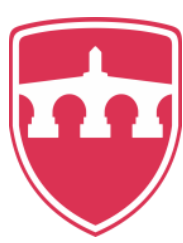

INTERNATIONAL BALKAN

UNIVERSITY

Sponsored by IBU

\title{
Girişimci ve İhracat Kararı: İhracat Yapan ve Yapmayan İşletmelerde Karşılaştırmalı Bir Araştırma* $^{*}$
}

\author{
Entrepreneur and Export Decision: A Comparative Research on Exporting and Non-Exporting \\ Companies
}

\author{
Esra Sena Türko** - Berrak Yellice ${ }^{* * *}$
}

\begin{abstract}
Plenty of research indicates that differences between exporting and non-exporting companies exist according to entrepreneur's traits. Revealing which traits of the entrepreneurs differ from each other, contributes to design and implement appropriate intervention tools to increase the export rate of an industry or a region. The aim of this study is to investigate the effects of the entrepreneur's personality traits on export decision. With this aim, differences between exporting and non-exporting companies, on entrepreneur's personality traits and variables representing perception on exporting are investigated. According to exporting status; mean ranks for two groups differ significantly from each other in three variables among six variables representing personality traits of the entrepreneur; and two variables among five variables representing perception on exporting. Compared to owners of the non-exporting companies, owners of the exporting-companies seem to have higher scoring for visiting abroad frequently, attending to fairs and taking risk. Compared to exporting-companies, non-exporting companies have higher scores for expressing that exporting requires big capital and big company scale. The relationship between export rate and entrepreneur's personality traits are investigated, and very weak positive relations are detected, in the study. Besides, relationship between entrepreneur's personality traits; and reasons of exporting, reasons for not-exporting and variables representing perception on exporting are investigated. The study includes a field research applied to 246 firms operating in textile industry in Bursa. Data set is analyzed with One-Sample Kolmogorov-Smirnov test, Mann-Whitney U test and Spearman's correlation.
\end{abstract}

\footnotetext{
* Bu çalışma, 7-8 Eylül 2018 tarihinde Didim/Aydın'da düzenlenen IV. Uluslararası Kafkasya-Orta Asya Dış Ticaret ve Lojistik Kongresi'nde "Kişisel özellikler kararları etkiler, peki ya ihracat kararını? İhracat yapan ve yapmayan işletmelerde karşılaştırmalı bir uygulama" başlı̆̆ıyla sunulan bildiriden üretilmiştir.

*** Dr. Öğr. Üyesi, Erzurum Teknik Üniversitesi, İktisadi ve İdari Bilimler Fakültesi, İktisat Bölümü

Asst. Prof. Dr., Erzurum Technical University, Faculty of Economics and Administrative Sciences, Department of Economics

ORCID 0000-0002-9102-6120

esturko@erzurum.edu.tr

**** Öğr. Gör., Ağrı İbrahim Çeçen Üniversitesi, Meslek Yüksekokulu, D1ş Ticaret Bölümü

Lect., A ̈̆rı İbrahim Çeçen University, Vocational School, Department of Foreign Trade

ORCID 0000-0001-9991-5689

byellice@agri.edu.tr

Cite as/ Atıf: Türko, E. S., Yelice, B. (2020). Girişimci ve ihracat kararı: ihracat yapan ve yapmayan işletmelerde karşıllaştırmalı bir araştırma, Turkish Studies - Economy, 15(1), 557-576. https://dx.doi.org/10.29228/TurkishStudies.39766

Received/Geliş: 15 November/Kasım 2019

Accepted/Kabul: 25 March/Mart 2020

Copyright $(\mathcal{C}$ INTAC LTD, Turkey

Checked by plagiarism software

Published/Yayın: 30 March/Mart 2020

CC BY-NC 4.0
} 


\section{Structured Abstract: Introduction}

The aim of this study is to investigate the effects of the entrepreneur's personality traits on export decision. With this aim, the study is built on a field survey. Differences between exporting and non-exporting companies, on entrepreneur's personality traits and variables representing perception on exporting are investigated. Besides, the relationships between export rate, entrepreneur's personality traits, reasons for exporting, reasons for not-exporting and variables representing perception on exporting are examined. Prominent models of export decision in the literature, critics of these models and recent applied studies are mentioned in the study. And the results of research, specifically focusing on entrepreneurs in export decision process, are reviewed. The study aims to contribute to better understanding of export decision process, at company level.

Plenty of research indicates that differences between exporting and non-exporting companies exist according to entrepreneur's traits (Cavusgil \& Naor, 1987; Ward, 1993; Beamish \& Dhanaraj, 2003; Brooks \& Rosson, 1982; Koh, 1991; Bilkey \& Tesar, 1977). Revealing which traits of the entrepreneurs differ from each other, contributes to design and implement appropriate intervention tools to increase the export rate of an industry or a region.

\section{Method and Analysis}

The study includes a field research applied to 246 firms operating in textile industry in Bursa. Bursa is a pioneering textile production region; and export is very widespread and has been supported by incentives for long years in the textile industry. Survey tool is prepared by the researchers after a broad literature review and deep company interviews carried out in Bursa. Questions are presented in 5 point Likert Scale.

In order to choose the convenient analysis method, data set is evaluated with standardized OneSample Kolmogorov-Smirnov test. Data set has not shown normal distribution $(\mathrm{p}=0,00<0,05)$. Statistically significant difference between exporting and non-exporting companies among various variables are analyzed with non-parametric Mann-Whitney U test; and relations between variables are analyzed with non-parametric Spearman's correlation.

\section{Results and Discussion}

Analysis results indicate that there is statistically significant difference between exporting and nonexporting companies among expressing; exporting requires big company scale and exporting requires big capital. Compared to exporting-companies, non-exporting companies have higher scores for expressing that exporting requires big capital and big company scale. There is no statistically significant difference between two groups among expressing; exporting is risky, exporting is very profitable and exporting is a sign of success for a company.

Statistically significant difference has been detected between exporting and non-exporting companies among three variables representing personality traits of the entrepreneur. Compared to owners of the nonexporting companies, owners of the exporting-companies seem to have higher scoring for visiting abroad frequently, attending to fairs and taking risk. Research results support related literature (Brooks \& Rosson, 1982; Denis \& Depelteau, 1985; Cavusgil \& Naor, 1987; Dichtl et al., 1990; Davidsson, 1991; Daniele, 1994; Koçak, 1997; Bernard \& Wagner, 1997; Bernard \& Jensen, 1999; Danışman \& Sökmen, 2007).

On the other hand, mean ranks for two groups do not differ significantly from each other in three variables representing personality traits of the entrepreneur. Entrepreneurs of exporting and non-exporting companies; are open to change, attend to trainings and seminars and buy consultancy services, at similar levels. This result can be interpreted in two ways. For the companies in the sample, activities of attending to trainings and seminars and buying consultancy services may not be related with export activities. On the other hand, if these two activities are presumed to be related with export activities, as market research abroad and technical/bureaucratic support for export operations, then the research results reveal a consequence that does not support the related literature. According to the related literature, information gathering processes positively influence export decision (Johanson \& Weidersheim-Paul, 1975; Cavusgil, 1980; Sood \& Adams, 1984; Cavusgil \& Naor, 1987; Koçak, 1997; Danışman \& Sökmen, 2007). But it can be thought that, the company would need this information and support at first export decision and/or while carrying out the first export operation; thus may not need an external support in the following operations, with the experience and 
institutional capital it has gained. Also, it should be noted that, as the scale of the company rises, there may be departments within the company, where export operations are carried out.

When analysis results of comparing two groups are summarized; compared to exporting companies, non-exporting companies seem to have higher scores for expressing that exporting requires big capital and big company scale; and lower scores for visiting abroad frequently, attending to fairs and taking risk.

The relationship between export rate and entrepreneur's four personality traits- open to change, visiting abroad frequently, attending to fairs and taking risk- are investigated, and very weak positive relations are detected, in the study. As the level of expression of entrepreneur is open to change, visit abroad frequently, attend to fairs and take risk increases, export rate increases. This result supports the related literature (Bilkey \& Tesar, 1977; Koh, 1991; Thompson, 1999). There is no statistically significant relationship detected between export rate and entrepreneur's two personality traits- attending to trainings and seminars and buy consultancy services.

Relationship between entrepreneur's personality traits; and reasons of exporting, reasons for notexporting and variables representing perception on exporting are investigated. Some important results can be summarized as follows: When relations between variables about reasons for not-exporting and entrepreneur's personality traits are evaluated together, there may be a grouping criteria for the companies. Companies expressing lack of knowledge on processes and markets are considered to represent a group of companies that could be guided to export. Entrepreneurs; are open to change, attend trainings and seminars, and buy consultancy services. They may be considered to be in a process of gathering information and receiving support which may influence export decision positively; and/or if the so called activities are not related with export, then these companies should be encouraged to take export oriented trainings, seminars and consultancy services. Companies expressing that their production is for domestic market, the non-exporting status is considered to be a market choice. Entrepreneurs are open to change, and there is no negative relationship detected between other variables about personality traits. Companies expressing satisfaction on current production and sales are considered to represent a more closed group of companies. Negative relations are detected on five of six entrepreneur's traits presented. Companies expressing that they are not big enough to make export are considered to represent a prejudiced company group. Encouraging entrepreneurs to visit abroad may contribute to eliminate this prejudice.

Expressions stressing that exporting requires big capital and big company scale; is detected as a difference between exporting and non-exporting companies; and correlated with not exporting reason- lack of knowledge on processes and markets. When these two results are evaluated together, existence of a prejudice is considered. Sharing more success stories of small and medium sized enterprises by chambers of commerce, export unions and producer unions, will contribute to eliminate this prejudice and encourage companies for exporting processes.

Keywords: Export, Export Decision, Entrepreneur, Bursa, Turkey.

Öz: Birçok araştırma ihracat yapan işletmelerle ihracat yapmayanlar arasında girişimci özelliklerine bağlı farklılıkların bulunduğunu göstermektedir. Girişimcilerin hangi özellikleri açısından farklılık bulunduğunun tespit edilmesi, ihracatın artırılmasının istendiği endüstri veya bölge için uygun müdahale araçlarının tasarlanmasına ve kullanılmasına katkıda bulunmaktadır. Bu çalışmanın amacı, girişimcinin kişisel özelliklerinin ihracat kararı üzerindeki etkisini araştırmaktır. Bu amaçla çalışmada, ihracat yapan ve yapmayan işletmeler arasında, girişimcinin çeşitli özellikleri ve ihracat konusunda algı düzeyini ifade eden çeşitli değişkenler açısından fark bulunma durumu araştırılmıştır. Analiz sonucuna göre, girişimcinin çeşitli kişisel özelliklerini ifade eden altı değişkenin üçünde ve ihracat algı düzeyi konusunda sunulan beş ifadenin ikisinde, ihracat yapma durumu açısından iki grup arasında istatistiksel olarak anlamlı bir farklılık bulunmaktadır. İhracat yapan işletmelerin sahipleri, ihracat yapmayanlara kıyasla daha yüksek düzeyde sık sık yurtdışına çıkmakta, fuarlara katılmakta ve risk üstlenmektedir. İhracat yapmayan işletmeler, ihracat yapan işletmelere kıyasla daha yüksek düzeylerde ihracat yapmak için büyük sermaye gerektiğini ve büyük ölçekli işletme olmak gerektiğini ifade etmiştir. Çalışmada ihracat oranı ile girişimcinin çeşitli özellikleri arasında ilişki bulunma durumu incelenmiş, çok zayıf pozitif yönlü ilişkiler tespit edilmiştir. Ayrıca, girişimcinin çeşitli özellikleri ile; ihracat yapma nedenleri, ihracat yapmama nedenleri ve ihracat konusunda algı düzeyini ifade eden çeşitli değişkenler açısından ilişkiler araştırılmıştır. Çalışma Bursa'da tekstil 
endüstrisinde faaliyet gösteren 246 işletmeye uygulanan bir saha araştırması içermektedir. Veri seti, TekÖrneklem Kolmogorov-Smirnov testi, Mann-Whitney U testi ve Spearman korelasyon katsayısı kullanılarak analiz edilmiştir.

Anahtar Kelimeler: İhracat, İhracat Kararı, Girişimci, Bursa, Türkiye.

\section{Giriş}

İhracat, büyümenin önemli bir kaynağı olarak klasik dış ticaret teorilerinden günümüze dek çokça tartışılan ve araştırılan bir konu olmuştur. Ülkeler ihracatlarını arttırmak amacıyla makro düzeyde çeşitli politikalar uygulamakta, mikro düzeyde işletmelerin ihracat davranışını ortaya çıkaracak ve geliştirecek bir yatırım ortam yaratmaya çalışmaktadır. Türkiye gibi ihracata dayalı büyüme modeli benimseyen ülkelerde ihracatın her açıdan çokça çalışıldığı görülmektedir. $\mathrm{Bu}$ bağlamda ihracat yapan işletmelerin sorunları (Çoban, 2005; İnan ve Nakıboğlu, 2009; Sönmez ve Arslan, 2007; Ersungur ve Yalman, 2009; Kılıç, 2007), işletmeleri ihracattan alıkoyan nedenler (Acılar vd., 2015; Ağan ve Erdoğan, 2016), hangi işletmelerin ihracat yaptıkları veya daha yüksek ihracat performansı gösterdikleri (Çütçü, 2013; Kahveci, 2012 ve 2013), ihracat teşviklerinin etkililiği (Ersungur ve Takım, 2018; Aktürk ve Şenol 2010; Durman vd. 2007; Takım ve Ersungur, 2010), hangi makro ekonomik göstergeler ile ihracat miktarının ilişkili olduğu (Çütcü ve Cenger, 2017; Gediz ve Yalçınkaya, 2004; Gozgor ve Piskin, 2011; Doğanlar vd., 2003) gibi hususlar araştırmacıların ilgisini çekmiştir.

Yapılan birçok araştırma ihracat yapan işletmelerle ihracat yapmayanlar arasında girişimci özelliklerine bağlı farkl1lıkların bulunduğunu göstermektedir (Cavusgil ve Naor, 1987; Ward, 1993; Beamish ve Dhanaraj, 2003; Brooks ve Rosson, 1982; Koh, 1991; Bilkey ve Tesar, 1977). Girişimcilerin hangi özellikleri açısından farklılık bulunduğunun tespit edilmesi, ihracatın artırılmasının istendiği endüstri veya bölge için uygun müdahale araçlarının tasarlanmasına ve kullanılmasına katkıda bulunmaktadır.

Türkiye'de ihracat üzerine çok çalışma yapılmış olmasına rağmen ihracat karar süreci daha az incelenen bir konu olarak kalmıştır. Bu çalışmanın amacı, girişimcinin kişisel özelliklerinin ihracat kararı üzerindeki etkisini araştırmaktır. Araştırma bu amaca uygun olarak tasarlanmış bir saha araştırması üzerine bina edilmiştir. Çalışmada, ihracat yapan ve yapmayan işletmeler arasında, girişimcinin çeşitli özellikleri ve ihracat konusunda algı düzeyini ifade eden çeşitli değişkenler açısından fark bulunma durumu araştırılmıştır. Ayrıca ihracat oranı, girişimcinin çeşitli özellikleri, işletmelerin ihracat yapma/yapmama nedenleri ve ihracat alg1 düzeyi arasındaki ilişkiler incelenmiştir. Saha araştırmasının, ihracatın çok yaygın olduğu ve uzun yıllardır teşviklerle desteklenen tekstil endüstrisinde gerçekleştirilmesi tercih edilmiştir. Araştırmada öncelikle yazında ihracat kararı konusunda geliştirilen belli başı modellerden, bu modellere yöneltilen eleştirilerden ve son zamanlarda gerçekleştirilen uygulamalı çalışmalardan bahsedilmektedir. Ardından ihracat karar süreci içinde spesifik olarak girişimciyi konu alan çalışmaların sonuçları paylaşılmıştır. Araştırma, işletme düzeyinde ihracat karar sürecinin daha iyi anlaşılmasına katkıda bulunmayı amaçlamaktadır.

\section{İhracat Kararı}

İhracat karar süreci; girișimcinin özellikleri, işletmenin özellikleri, bunlar arasındaki etkileşim ve dışsal faktörlerin etkisi ile ortaya çıkan karmaşık bir süreç olarak tanımlanmaktadır. İhracat karar süreci, ihracat konusunda bilgi edinmeyle başlayıp benimseme veya benimsememe kararına uzanan bir mantık sürecidir. Söz konusu süreç işletmelerin ihracat fikrini keşfetmesi ve haberdar olması ile başlar, pazar araştırması ve bilgi toplama faaliyetleri, değerlendirme ve ihracat kararını vermesi ile sonuçlanır (Koçak, 1997: 468-476). 
Andersen (1993), firmaların uluslararasılaşma süreçleri konusunda geliştirilen modelleri irdelediği çalışmasında, yazında önde gelen iki modeli ele almıştır: Johanson, Vahlne ve Wiedersheim-Paul tarafindan geliştirilen "Uppsala uluslararasılaşma modeli" (U-M) ve uluslararasılaşmayı firmanın inovasyonu olarak ele alan "inovasyonla ilgili uluslararasılaşma modelleri (I-M) (Andersen, 1993: 209).

Uppsala Üniversitesi akademisyenlerinin öncü çalışmaları nedeniyle (Johanson and Wiedersheim-Paul, 1975; Johanson and Vahlne, 1977) model bu isimle anılmaktadır. Modele öncülük eden çalışma 4 İsveç üreticisinin gözlemine dayanmaktadır ve Penrose (1959), Cyert \& March (1963), Aharoni (1966) Vernon (1966) çalıșmalarından etkilenmiștir (Zohari, 2008). U modeli eleștirilere rağmen yaygın bir șekilde kabul görmüştür ve uluslararası işletme araştırmalarını etkilemeye devam etmektedir (Tan vd., 2018: 47).

U-M modelini ortaya koyan yazarların çalışmaları aynı zamanda I-M modellerinin geliştirilmesine ilham kaynağı olmuştur. U ve I modellerinin ikisi de davranışsal bir yaklaşım üzerine kuruludur, uluslararasılaşmayı bir süreç olarak ele almaktadır. U-modeli öğrenme teorisine yaptığ1 vurguyla dinamik bir modeldir. I-modelleri ise uluslararasılaşma sürecini adım adım ilerleyen bir gelişme ile resmetmektedir ve Rogers'ın (1962) uyarlama süreçlerinden çıkarılmıştır (Andersen, 1993: 212, 216). I-M modellerinin öncü çalışmaları Bilkey ve Tesar (1977), Cavusgil (1980), Czinkota (1982) ve Reid (1981) olarak siralanabilir (Andersen, 1993: 213).

Uluslararası yeni girişimler teorisi (INV) (Oviatt \& McDougall, 1994); işlem maliyetleri, kaynak-tabanlı bakış, kurumsal yönetim ve uluslararası girişimcilik gibi birden fazla teorik perspektifi birleştirerek, ihracat faaliyetlerini içsel ve dışsal güçlerin arasındaki etkileşimler olarak açıklamaktadır. Uppsala modeli ve INV, ihracatın başlangıcını birbirini tamamlayan iki farklı bakış açısıyla anlatmaktadır (Yi ve Wang, 2012: 767).

Johanson ve Weidersheim-Paul (1975: 304-307) tarafindan ortaya konulan modelde; dil, kültür, politik sistem, eğim seviyesi, ekonomik gelişmişlik düzeyi gibi faktörler bakımından benzer olan ülkelerde faaliyette bulunmanın, işletmeler için daha çekici faktörler olduğu anlatılmaktadır. Modele göre ihracat yapmak için büyük bir kaynak ve bilgi birikimi gerekmektedir. Bu nedenle işletmelerin başlangıçta yerel piyasalarda tecrübe kazandıktan sonra aşamalı olarak geliştikleri ve dışa açıldıkları belirtilmektedir.

Cavusgil ve Nevin (1981: 115) çalışmalarında ihracat davranışını belirleyen dört unsur tespit etmişlerdir. İşletme sahibinin ihracat konusundaki uzun vadeli beklentileri, kararlılığı (örgütsel bağl1lığı) ve arzusu bu unsurların üçünü oluşturmaktadır. Çalışmanın dördüncü unsuru ise işletmelerin sahip olduğu üstünlüklerdir. Çalışmada önerilen dört unsurun üçü girişimci ile ilgilidir.

İktisat literatüründe heterojen firma ticaret modelleri, ihracat faaliyetlerinin firma düzeyinde analizleriyle ortaya çıkmıştır. Heterojen firma modelleri; U modeli ve INV teorileri tarafından ihracatın geçmişi konusunda ihmal edilen batık maliyetlerin önemini işaret etmektedir. Aynı zamanda endüstri düzeyinde ve makro düzeyde analizlere odaklanan geleneksel ve yeni ticaret teorilerinden farklı olarak ihracatı, firmanın bakış açısıyla anlamaya çalışmışlardır (Greenaway, Guariglia ve Kneller, 2007: 377; Yi ve Wang, 2012: 767).

Heterojen firma modellerinde firmanın ihracat yapıp yapmaması verimliliği ile ilgilidir. Melitz'in heterojen firmalar ve ihracatta sabit maliyetleri konu alan modelinde, en verimli üretici firmalar yurtiçi ve yurtdışı pazarlarda, orta düzeyde verimliliğe sahip firmalar sadece yurtiçinde ürünlerini satarlar; en verimsiz firmalar ise pazardan çıkarlar (Melitz, 2003).

İhracat kararının verilmesi üzerinde etkili olan faktöreler: risk, kâr, eğitim, haberleşme, maliyet ve üretim süreçlerinden oluşmaktadır. Ayrıca belirsizlik; işletmelerin ihracat kararının, ürün satışlarının ve ihracat potansiyelinin yanı sıra üretim artışını ve maliyet düşürme faaliyetlerini de olumsuz etkiler (Sousa vd., 2016: 6). 
Özler vd., (2009) Türk imalat sanayi işletmelerinin 1990-2001 yılları arasındaki ihracat kararlarını araştırmıştır. Araştırma sonuçları, işletmenin ihracat kararının önceki ihracat tecrübelerinden etkilendiğini göstermektedir; ancak geçmiş tecrübenin etkileri, hızla güncel tecrübenin etkileri karşısında değer kaybetmektedir. İhracatta süreklilik, pazara tekrar giriş maliyetlerinin düşmesini sağlamaktadır.

İhracat engelleri, ihracat kararı konusunda gerçekleştirilen çalışmaların diğer odak noktalarından biridir. Dış ticarette kayıtdış1/görünmez engeller, pazar bilgisi toplama, müşterilerle bağlantı kurmak ve ulusal standartlara ve yönetmeliklere uygun düzenlemeler yapmanın maliyetleri sayılabilir. Bu engellerin azaltılması dış pazarlara girişte engelleri aşmayı amaçlayan bir politika gerektirmektedir (Medin, 2003: 238).

Gümrük uygulamaları konusundaki bilgi, doğrudan ihracat yapma isteğini arttırmaktadır (Co vd., 2018). Girdilere uygulanan tarifeler ile işletmenin ihracat yapma durumu arasındaki iliş̧kiyi Arjantin'de firma düzeyinde araştıran bir çalışmanın sonuçlarına göre, girdi tarifelerinde daha fazla düşüş yaşanan endüstrilerde firmaların ihracata başlama oranları daha yüksektir (Bas, 2012: 481-482).

Firmaların algıladıkları engeller ve algıladıkları faydaların ihracat kararının verilmesinde etkili olduğu düşünülebilir. Avustralya'da gerçekleştirilen bir araştırmada bazı firmaların engellere rağmen ihracat yaptıkları, bazı firmaların ise engel görmedikleri halde ihracat yapmadıkları kaydedilmiştir (Ramaseshan ve Soutar, 1996: 53).

İhracat kararı ve işletmenin Ar-Ge faaliyetleri arasındaki ilişkiyi araştıran çok sayıda uygulamalı çalışma bulunmaktadır (Braymen vd. 2011; Tomiura, 2007). Sigeze vd., (2016) Türk işletmelerinde Ar-Ge ve ihracat kararı arasında pozitif yönlü bir ilişki bulmuşlardır. Ayrıca araştırma bulgularına göre; devlet destekleri, işletmenin ihracat kararı olasılığını yükseltmektedir; Ar-Ge ve ihracat kararı, işletme özelliklerine göre farklılık göstermektedir.

Ayrıca ihracat kararının; planlama ve doğaçlama (Nemkova vd., 2012); pazarlar konusunda bilgi kaynakları (He ve Wei, 2013; Inui vd., 2015); standartlar ve teknik düzenlemeler Chen vd., 2008); yı ğılma (Koenig, 2009); ağ faaliyetleri (Tomiura, 2007); insan sermayesi (Gashi, 2014); politik istikrarsızlık (Kapri, 2018), kurlarda belirsizlik (Greenaway vd., 2010; Wong, 2016) ile ilişkisini araştıran çalışmalar bulunmaktadır.

\section{İhracat Kararında Girişimcinin Kişilik Özellikleri}

İşletme sahibinin özelliklerinin ihracat kararı üzerindeki etkisini araştıran çalışmalar genellikle işletme sahibinin yaşı, eğitimi, yabancı dil bilgisi, yurtdışı deneyimleri, ihracatı algılama şekli, bilgi toplama eğilimi, pazar bilgisi araştırma ve yeniliği benimseme gibi özelliklerini işletmenin ihracat davranışı ile ilişkilendirmektedir (Türko ve Yellice, 2017: 302).

Johanson ve Weidersheim-Paul (1975) ihracatın pazar bilgisi ve deneyim gerektirdiğini bu nedenle işletmelerin ihracat faaliyetine yurt içinde geliştikten sonra aşamalı olarak başlayabileceklerini belirmişlerdir. Bilkey ve Tesar (1977) girişimci özellikleri ve dinamizmini ihracat kararında en önemli unsurlar olarak tanımlamışlardır.

Cavusgil (1980) ihracat karar sürecinde, veri sağlanması ve pazar araştırmasının en önemli faktörler olduğunu belirtmiştir. Bu süreç, iç pazara yönelik açıklama, ihracat öncesi aşama, artan tecrübeyle ihracatta pasif yoğunlaşma, aktif yoğunlaşma ve kendi ihracat bağlantılarını kurma şeklindedir. Sood ve Adams (1984: 176) özellikle bilgi toplama eğiliminin ihracat karar sürecini olumlu yönde etkilediğini ortaya koymuşlardır.

Koçak (1997) tarafindan gerçekleştirilen saha araştırmasında, Türkiye'de 11 ilde ve dört sektörde faaliyet gösteren işletmelerle görüşülerek bir ihracat karar süreci modeli geliştirilmiştir. Araştırma bulguları ihracat kararı üzerinde en önemli etkinin işletme sahiplerinin fuarlara katılma 
eğilimi olduğunu göstermektedir, ardından sırasıyla yurtdışına yatkınlık ve yurtdışına çıkma sıklığı gelmektedir. İşletme sahibinin eğitim düzeyi, yabancı dil bilgisi ve ihracata karşı tutumun daha düşük düzeylerde etkisi olan faktörler olarak kaydedilmiştir. İşletme sahibinin yaşı ve değişime yatkınlığının, ihracat karar sürecinde etkili faktörler olmadığı belirlenmiştir.

Girişimcilerin risk alma eğiliminin ihracat performansında önemli bir etkiye sahip olduğu görülmektedir (Daniele, 1994; Denis ve Depelteau, 1985; Brooks ve Rosson, 1982; Bernard ve Wagner, 1997; Bernard ve Jensen, 1999; Dichtl vd., 1990; Davidsson, 1991; Cavusgil ve Naor, 1987).

Türko ve Yellice (2016) tarafından belirsizliğe tolerans düzeyinin ihracat kararı üzerindeki etkisinin araştırıldığı çalışmada; girişimcilerin belirsizliğe tolerans düzeyi ile ihracat oranının da içinde bulunduğu 21 değişken arasında anlamlı bir ilişki bulunmamış; belirsizliğe tolerans düzeylerinin, ihracat yapan ve yapmayan işletmelerde istatistiksel olarak anlamlı bir farkl1lık göstermediği sonucuna ulaşmıştır.

Girişimcinin eğitimi, yabancı dil bilgisi, tecrübesi ve ihracat yeteneği; işletmenin ihracat yapma isteğini şekillendirmektedir (Çetin, 2016: 44). Suarez-Ortega ve Alamo-Vera, (2005: 262) çalışmalarında, daha iyi eğitim seviyesine sahip olan girişimcilerin daha açık fikirli ve uluslararası gelişmelere daha fazla ilgili olacağ 1 düşüncesine dayanarak, eğitim seviyesi ile ihracat gelişim seviyesi arasında aynı yönlü ilişki beklemektedir.

Thompson (1999)'a göre girişimcilerin pazar araştırmalarına ve yeniliğe verdiği önem, ziyaret ya da başka yollarla yabancı pazarlar hakkında bilgi edinebilme becerileri ve başarıya duydukları isteklerin, işletmelerin ihracat performansı üzerinde etkisi olacaktır (Danışman ve Sökmen, 2007: 217). Diğer yandan girişimcilerin ihracat konusunda tutumlarının, işletmelerin ihracatını ve başarısını doğrudan etkilediğini gösteren çalışmalar bulunmaktadır (Zou ve Stan, 1998; Aaby ve Slater, 1988; Louter vd., 1991; Nemkova vd., 2012).

Cavusgil ve Naor (1987: 223) ihracatın algılanışı üzerine durarak yaşın, eğitim düzeyinin, yabancı dil bilgisinin, yurtdışı deneyimlerinin ve bilgi toplama eğiliminin ihracat kararında etkili faktörler olduğunu belirtmişlerdir (Koçak, 1997: 471-473).

Yönetim, ihracat kararından doğrudan sorumlu olması nedeniyle, işletmenin ihracat çabalarının başlatılmasının, geliştirilmesinin, sürdürülmesinin ve başarısının arkasındaki temel güç olarak kabul edilir (Shamsuddoha, 2004: 25). Yöneticilerin eğitimi, yabanc1 dil bilgisi, ihracat deneyimleri, algı ve davranışları işletmelerin ihracat kararında etkili olmaktadır. Yurtdışında eğitim görmüş ihracat yöneticileri, ihracat yapan işletmelere daha fazla katkı sağlar ve başarı getirir (Koh, 1991: 53). Kanada'da faaliyet gösteren başarılı ihracatçı işletmelere yönelik yapılmış bir çalışma, en üst düzeydeki yöneticilerin çeşitli yönetimsel özelliklerinin, başarılı ihracat yapmanın anahtar faktörü olabileceğine dikkat çekmektedir (Kammath vd., 1989'den aktaran Das, 1994). KOBI'lerin üst düzey yöneticilerinin sık sık yurtdışına gitmeleri, daha çok pazar araştırması yapmaları ve böylece yabanc1 pazarlar konusunda daha kapsamlı bilgilere sahip olmaları işletmelerin ihracatlarına yansımaktadır (Danışman ve Sökmen, 2007: 225). Ancak, işletme yöneticilerinin yeniliğe açık olmasının, eğitim düzeyinin ve yabancı dil bilgisinin, ihracata yönelik tutum üzerinde, girişimcilere kıyasla daha düşük bir etkiye sahip olduğu belirlenmiştir (Koçak, 1997).

İhracat yapan işletmelerde girişimciyi daha iyi anlamaya yönelik yakın zaman araștırmalarında kullanılan kavramlardan biri de ihracat girișimciliğidir. İhracat girișimciliği, bireylerin, mevcut kaynakları ve kendilerini etkileyen çevresel faktörleri dikkate alarak, kendi başlarına veya organizasyonları içinde yabancı pazar firsatlarından faydalandıkları süreç olarak tanımlanmaktadır. Bu tanım ihracat girişimciliğinin içsel (kaynaklar gibi) ve dışsal (çevre gibi) faktörlere bağımlılığına vurgu yapmaktadır. İlgili yazında ihracat girişimciliğinin içsel belirleyicileri; ihracat karar alıcıların kişisel faktörleri ve organizasyonun kaynak ve kabiliyetleri ile ilgilidir. İhracat yöneticisinin ihracata karşı tutumu, ihracat bağlılığının bir yansıması olarak, 
içsel faktörler içinde yer almaktadır (Ibeh ve Young, 2001; Navarro-García, Schmidt ve ReyMoreno, 2015: 153).

\section{Yöntem}

Saha araştırmasının tekstil endüstrisinde faaliyet gösteren işletmelerde yürütülmesi ve Bursa'da gerçekleştirilmesi tercih edilmiştir. Tekstil endüstrisinde ihracat çok yaygındır ve uzun yıllardır teşviklerle desteklenmektedir. Bursa Ticaret ve Sanayi Odası'na kayıtlı 1.582 hazır giyim ve konfeksiyon işletmesi ve 3.749 tekstil işletmesi ve bulunmaktadır. Çalışmanın ana kütlesi bu iki sektörde faaliyet gösteren toplam 5.331 işletmeden oluşturmaktadır. Örneklem sample size calculator uygulaması kullanılarak \%95 güven aralığında ve 0,05 önem seviyesinde 358 olarak hesaplanmıştır (Survey System, 2017). Saha araştırması 2016 yılı Temmuz ve Ağustos aylarında, 15 Temmuz darbe girişiminden hemen sonra gerçekleştirilmiştir. Söz konusu dönemde, Türkiye’de olağanüstü koşullar geçerli olmuş, işletme ziyaretleri çok zorlaşmış, işletmeler ankete katılmak istememiştir. 478 işletme ziyaret edilmiş, 356 anket uygulanmış; ancak 100 anket çeşitli sebeplerle kullanılamamıştır. Araştırma kapsamında ancak 246 anket değerlendirmeye alınabilmiştir.

Anket formu, geniş bir literatür araştırması ve Bursa'da işletmelerle derinlemesine görüşmeler yapıldıktan sonra araştırmacılar tarafindan oluşturulmuştur. Sorular 5'li Likert Ölçeği ile seçeneklendirilmiştir (1-kesinlikle hayır, 2-hayır, 3-kararsızım, 4-evet, 5-kesinlikle evet). Anket formu 4 ana bölümden 22 sorudan oluşmaktadır. Birinci bölümde işletmeler hakkında genel bilgiler, ikinci bölümde işletmelerin neden ihracat yaptıkları ve yapmadıklarını araştıran sorular, üçüncü bölümde işletmelerin ihracat alg1 düzeyine ilişkin sorular ve dördüncü bölümde girişimcilerin çeşitli özelliklerine ilişkin sorular bulunmaktadır. Anketler, Bursa'da yer alan DOSAB, NOSAB, KESTEL ve GÜRSU organize sanayi bölgelerinde ve BUTTIM iş merkezinde yer alan işletmelere uygulanmıştır. Yapılan görüşmeler doğrudan işletme sahipleriyle veya işletmede çalışan üst düzey (genel müdür, diş ticaret müdürü vb.) yöneticilerle, bizzat araştırmacılardan biri tarafından doğrudan işletme ziyaretleriyle gerçekleştirilmiştir.

\section{Analiz}

İhracat yapan ve yapmayan işletmeler arasında, çeşitli değişkenler açısından anlamlı bir farklılık bulunma durumunu araştırmak amacıyla kullanılacak fark testinin ve korelasyon analizinin seçimi için, veri seti kategorize edilmiş değişkenler Tek Örneklem Kolmogorov-Smirnov testi ile değerlendirilmiştir. Değişkenlerin normal bir dağılım göstermediği tespit edildikten sonra $(\mathrm{p}=$ $0,00<0,05)$ değişkenler arasında ihracat yapma durumuna göre farklılık bulunma durumunu tespit etmek için parametrik olmayan Mann-Whitney U testinin kullanılmasına karar verilmiştir. Tablo gösteriminde kolaylık olması için ihracat yapmayanlar "0", ihracat yapanlar "1" kodlarıyla kategorize edilmiştir. İhracat yapan ve yapmayan işletmeler arasında istatistiksel olarak bir fark bulunması durumunda $(\mathrm{p}<0,05)$ sıra ortalaması kalın olarak gösterilmiştir.

Değişkenler arasındaki ilişkileri analiz etmek için parametrik olmayan Spearman testinin kullanılmasına karar verilmiştir. Aralarında ilişki aranan değişkenlere ilişkin analiz sonuçları listelenmiştir. Önem düzeyine göre $p=, 00<0,01 ; p=, 00<0,05$ olduğu durumlarda, değişkenler arasında anlamlı bir ilişki bulunmaktadır (Durmuş vd., 2013: 198). Spearman Korelasyon Katsayısı (rs) değerlendirilmesinde kullanılan sınırlar: ,00-,19 “çok zayıf”; ,20-,39 “zayıf”; ,40-,59 “orta”; ,60-,79 "güçlü”; ,80-1,0 “çok güçlü” şeklindedir (Statstutor, 2016).

246 işletmeden oluşan örneklem içinde 117 işletme ihracat yapmakta 129 işletme ise yapmamaktadır. Veri seti SPSS 22 paket programı kullanılarak analiz edilmiştir. 


\section{İhracat Yapan ve Yapmayan İşletmeler Arasındaki Farklılıklar}

Tablo 1: İşletmelerin İhracat Alg1 Düzeyi Açısından Karşılaştırılması

\begin{tabular}{|c|c|c|c|c|c|c|c|c|}
\hline & & $\mathbf{N}$ & $\begin{array}{c}\text { Sira } \\
\text { Ortalaması }\end{array}$ & $\begin{array}{l}\text { Siraların } \\
\text { Toplamı }\end{array}$ & $\begin{array}{c}\text { Mann- } \\
\text { Whitney } \\
\text { U }\end{array}$ & $\begin{array}{l}\text { Wilcoxon } \\
\text { W }\end{array}$ & $\mathbf{Z}$ & $\underset{\text { Değeri }}{P}$ \\
\hline $\begin{array}{l}\text { İhracat yaparken } \\
\text { risk yüksektir. }\end{array}$ & $\begin{array}{l}0 \\
1\end{array}$ & $\begin{array}{l}129 \\
117\end{array}$ & $\begin{array}{l}128,59 \\
117,88\end{array}$ & $\begin{array}{l}16588,50 \\
13792,50\end{array}$ & 6889,500 & 13792,500 & $-1,341$ &, 180 \\
\hline $\begin{array}{l}\text { İhracat yapmak } \\
\text { için büyük } \\
\text { sermaye gerekir. }\end{array}$ & $\begin{array}{l}0 \\
1\end{array}$ & $\begin{array}{l}129 \\
117\end{array}$ & $\begin{array}{l}\mathbf{1 4 2 , 2 4} \\
102,84\end{array}$ & $\begin{array}{l}18348,50 \\
12032,50\end{array}$ & 5129,500 & 12032,500 & $-4,752$ &, 000 \\
\hline $\begin{array}{l}\text { İhracat yapmak } \\
\text { çok karlıdır. }\end{array}$ & $\begin{array}{l}0 \\
1 \\
\end{array}$ & $\begin{array}{l}129 \\
117 \\
\end{array}$ & $\begin{array}{l}119,22 \\
128,21 \\
\end{array}$ & $\begin{array}{l}15380,00 \\
15001,00 \\
\end{array}$ & 6995,000 & 15380,000 & $-1,064$ & ,287 \\
\hline $\begin{array}{l}\text { İhracat bir işletme } \\
\text { için başarı } \\
\text { göstergesidir. }\end{array}$ & $\begin{array}{l}0 \\
1\end{array}$ & $\begin{array}{l}129 \\
117\end{array}$ & $\begin{array}{l}119,31 \\
128,12\end{array}$ & $\begin{array}{l}15391,00 \\
14990,00\end{array}$ & 7006,000 & 15391,000 & $-1,074$ &, 283 \\
\hline $\begin{array}{l}\text { İhracat yapmak } \\
\text { için büyük ölçekli } \\
\text { işletme olmak } \\
\text { gerekir. }\end{array}$ & $\begin{array}{l}0 \\
1\end{array}$ & $\begin{array}{l}129 \\
117\end{array}$ & $\begin{array}{l}\mathbf{1 4 3 , 7 2} \\
101,21\end{array}$ & $\begin{array}{l}18540,00 \\
11841,00\end{array}$ & 4938,000 & 11841,000 & $-4,902$ & ,000 \\
\hline
\end{tabular}

Tüm örnekleme ihracat konusunda algı düzeyini gösterdiği düşünülen 5 ifade sunulmuş ve bu ifadelerde ihracat yapan ve yapmayan işletmeler arasında istatistiksel olarak anlamlı bir farklılık bulunma durumu Tablo 1'de gösterilmiştir. İhracat yapan ve yapmayan işletmeler arasında, ihracat yapmak için büyük ölçekli işletme olmak gerekir ve büyük sermaye gerekir ifadelerinde istatistiksel olarak anlamlı bir farklılık bulunmaktadır. İhracat yapmayan işletmeler, ihracat yapan işletmelere kıyasla, ihracat yapmak için büyük sermaye gerekir ve büyük ölçekli işletme olmak gerekir ifadelerine, daha yüksek düzeylerde cevap vermiştir. İhracat yaparken risk yüksektir, ihracat yapmak çok karlıdır ve ihracat bir işletme için başarı göstergesidir ifadeleri için iki grup arasında istatistiki olarak anlamlı bir farklılık bulunmamıştır; bu ifadelerde ihracat yapan ve yapmayan işletmeler benzer algı düzeyine sahiptir.

Tablo 2: İşletmelerin Girişimci Özellikleri Açısından Karşılaștırılması

\begin{tabular}{|c|c|c|c|c|c|c|c|c|}
\hline & & $\mathbf{N}$ & $\begin{array}{c}\text { Sira } \\
\text { Ortalaması }\end{array}$ & $\begin{array}{l}\text { Siraların } \\
\text { Toplamı }\end{array}$ & $\begin{array}{c}\text { Mann- } \\
\text { Whitney } \\
\text { U }\end{array}$ & $\begin{array}{c}\text { Wilcoxon } \\
\text { W }\end{array}$ & $\mathbf{Z}$ & $P$ Değeri \\
\hline $\begin{array}{l}\text { Değişime açık } \\
\text { biridir. }\end{array}$ & $\begin{array}{l}0 \\
1\end{array}$ & $\begin{array}{l}129 \\
117\end{array}$ & $\begin{array}{l}119,13 \\
128,32\end{array}$ & $\begin{array}{l}15367,50 \\
15013,50\end{array}$ & 6982,500 & 15367,500 & $-1,145$ &, 252 \\
\hline $\begin{array}{l}\text { Sik sik yurt } \\
\text { dişına çıkar. }\end{array}$ & $\begin{array}{l}0 \\
1 \\
\end{array}$ & $\begin{array}{l}129 \\
117 \\
\end{array}$ & $\begin{array}{l}114,89 \\
\mathbf{1 3 3 , 0 0} \\
\end{array}$ & $\begin{array}{l}14820,50 \\
15560,50 \\
\end{array}$ & 6435,500 & 14820,500 & $-2,109$ & ,035 \\
\hline Fuarlara katılır. & $\begin{array}{l}0 \\
1 \\
\end{array}$ & $\begin{array}{l}129 \\
117 \\
\end{array}$ & $\begin{array}{l}115,56 \\
\mathbf{1 3 2 , 2 6} \\
\end{array}$ & $\begin{array}{l}14907,00 \\
15474,00 \\
\end{array}$ & 6522,000 & 14907,000 & $-2,027$ & ,043 \\
\hline $\begin{array}{l}\text { Eğitimlere ve } \\
\text { seminerlere } \\
\text { katılır. }\end{array}$ & $\begin{array}{l}0 \\
1\end{array}$ & $\begin{array}{l}129 \\
117\end{array}$ & $\begin{array}{l}130,57 \\
115,70\end{array}$ & $\begin{array}{l}16844,00 \\
13537,00\end{array}$ & 6634,000 & 13537,000 & $-1,812$ &, 070 \\
\hline $\begin{array}{l}\text { Danışmanlık } \\
\text { şirketlerinden } \\
\text { hizmet satın } \\
\text { alır. }\end{array}$ & $\begin{array}{l}0 \\
1\end{array}$ & $\begin{array}{l}129 \\
117\end{array}$ & $\begin{array}{l}128,26 \\
118,26\end{array}$ & $\begin{array}{l}16545,00 \\
13836,00\end{array}$ & 6933,000 & 13836,000 & $-1,157$ &, 247 \\
\hline Risk üstlenir. & $\begin{array}{l}0 \\
1\end{array}$ & $\begin{array}{l}129 \\
117 \\
\end{array}$ & $\begin{array}{l}114,39 \\
\mathbf{1 3 3 , 5 5} \\
\end{array}$ & $\begin{array}{l}14756,00 \\
15625,00 \\
\end{array}$ & 6371,000 & 14756,000 & $-2,361$ & ,018 \\
\hline
\end{tabular}


Tüm örnekleme girişimcinin çeşitli özelliklerini temsil ettiği düşünülen 6 ifade sunulmuş ve bu ifadelerde ihracat yapan ve yapmayan işletmeler arasında istatistiksel olarak anlamlı bir farklılık bulunma durumu Tablo 2'de gösterilmiştir. İhracat yapan ve yapmayan işletmeler arasında, girişimcinin 3 özelliği açısından istatistiksel olarak anlamlı farklılık bulunmuştur. İhracat yapan işletmelerin girişimcileri, yapmayanlara kıyasla daha yüksek ortalamalarla sık sık yurt dışına çıkmakta, fuarlara katılmakta ve risk üstlenmektedir. Diğer yandan iki grup arasında girişimcinin 3 özelliği açısından istatistiksel olarak anlamlı farklılık bulunmamıştır. İhracat yapan ve yapmayan işletmelerin girişimcileri, benzer düzeylerde değişime açıktır, eğitim ve seminerlere katılır ve danışmanlık şirketlerinden hizmet satın alırlar.

Değişkenler Arasındaki İlişkiler

Tablo 3: İhracat Oranı ile Girişimcinin Özellikleri Arasındaki İlişkiler

\begin{tabular}{|c|c|c|c|}
\hline $\begin{array}{l}\text { 1. Değişken } \\
\text { İhracat } \\
\text { Oran }(\%)\end{array}$ & $\begin{array}{c}\text { 2. Değişken } \\
\text { Girişimci Özellikleri }\end{array}$ & $\begin{array}{c}\text { İlişkinin Yönü ve } \\
\text { Kuvveti }\end{array}$ & $r_{s}$, n ve $p$ değerleri \\
\hline \multirow{6}{*}{$\begin{array}{c}\text { Üretilen } \\
\text { ürünlerin } \\
\text { yurtdışına } \\
\text { satış oranı }\end{array}$} & Değişime açık biridir. & Çok zayıf $(+)$ & $r_{\mathrm{s}}=, 143 \mathrm{n}=246, \mathrm{p}<, 05$ \\
\hline & Sik sık yurtdışına çıkar. & Çok zayıf $(+)$ & $r_{\mathrm{s}}=, 167 \mathrm{n}=246, \mathrm{p}<, 01$ \\
\hline & Fuarlara katılır. & Çok zayıf $(+)$ & $r_{\mathrm{s}}=, 167 \mathrm{n}=246, \mathrm{p}<, 01$ \\
\hline & Eğitimlere ve seminerlere katılır. & İlişki yok & $r_{\mathrm{s}}=-, 105 \mathrm{n}=246, \mathrm{p}=, 101>, 01$ \\
\hline & $\begin{array}{l}\text { Danışmanlık şirketlerinden hizmet } \\
\text { satın alır. }\end{array}$ & İlişki yok & $r_{\mathrm{s}}=-, 037 \mathrm{n}=246, \mathrm{p}=, 563>, 01$ \\
\hline & Risk üstlenir. & Çok zayıf (+) & $r_{\mathrm{s}}=, 182 \mathrm{n}=246, \mathrm{p}<, 01$ \\
\hline
\end{tabular}

Tüm örneklemde, üretilen ürünlerin yurtdışına satış oranı (seçenekler: \%0, \%1-25, \%26-50, \%51-75, \%76-100) ile girişimcinin 6 özelliği arasında ilişki bulunma durumu araştırılmış ve ilişkiler Tablo 3'te sunulmuştur. İhracat oranı ile girişimcinin 4 özelliği- değişime açık biridir, sık sık yurt dışına çıkar, fuarlara katılır ve risk üstlenir ifadeleri- arasında pozitif yönlü çok zayıf ilişki bulunmaktadır. Girişimcinin değişime açık, sıklıkla yurtdışına çıkan, fuarlar katılan ve risk üstlenen bir kişi olduğu konusunda ifade düzeyi artıkça, ihracat oranı artmaktadır. İhracat oranı ile girişimcinin 2 özelliği- eğitim ve seminerlere katılır ve danışmanlık şirketlerinden hizmet satın alırarasında istatistiksel olarak anlamlı bir ilişki bulunmamıştır. 


\begin{tabular}{|c|c|c|c|}
\hline $\begin{array}{c}\text { 1. Değişken } \\
\text { İhracat Yapmama } \\
\text { Nedeni }\end{array}$ & $\begin{array}{c}\text { 2. Değişken } \\
\text { Girişimcinin Özellikleri }\end{array}$ & $\begin{array}{l}\text { İlişkinin } \\
\text { Yönü ve } \\
\text { Kuvveti }\end{array}$ & $r_{s}$, n ve $p$ değerleri \\
\hline \multirow{6}{*}{$\begin{array}{l}\text { Süreçler konusunda } \\
\text { bilgimiz yok. }\end{array}$} & Değişime açık biridir. & Zayıf (+) & $r_{\mathrm{s}}=, 293 \mathrm{n}=129, \mathrm{p}<, 01$ \\
\hline & Sik sık yurtdışına çıkar. & İlişki yok & $r_{\mathrm{s}}=, 150 \mathrm{n}=129, \mathrm{p}=, 089>, 01$ \\
\hline & Fuarlara katılır. & İlişki yok & $r_{\mathrm{s}}=, 027 \mathrm{n}=129, \mathrm{p}=, 763>, 01$ \\
\hline & $\begin{array}{l}\text { Eğitimlere ve seminerlere } \\
\text { katılır. }\end{array}$ & Çok zayıf $(+)$ & $r_{\mathrm{s}}=, 177 \mathrm{n}=129, \mathrm{p}<, 05$ \\
\hline & $\begin{array}{l}\text { Danışmanlık şirketlerinden } \\
\text { hizmet satın alır. }\end{array}$ & Çok zayıf $(+)$ & $r_{\mathrm{s}}=, 191 \mathrm{n}=129, \mathrm{p}<, 05$ \\
\hline & Risk üstlenir. & İlișki yok & $r_{\mathrm{s}}=-, 054 \mathrm{n}=129, \mathrm{p}=, 540>, 01$ \\
\hline \multirow{6}{*}{$\begin{array}{l}\text { Pazarlar konusunda } \\
\text { bilgimiz yok. }\end{array}$} & Değişime açık biridir. & Zayıf (+) & $r_{\mathrm{s}}=, 376 \mathrm{n}=129, \mathrm{p}<, 01$ \\
\hline & Sik sık yurtdışına çıkar. & Zayıf (+) & $r_{\mathrm{s}}=, 277 \mathrm{n}=129, \mathrm{p}<, 01$ \\
\hline & Fuarlara katılır. & İlişki yok & $r_{\mathrm{s}}=, 129 \mathrm{n}=129, \mathrm{p}=, 144>, 01$ \\
\hline & $\begin{array}{l}\text { Eğitimlere ve seminerlere } \\
\text { katılır. }\end{array}$ & Zayıf (+) & $r_{\mathrm{s}}=, 329 \mathrm{n}=129, \mathrm{p}<, 01$ \\
\hline & $\begin{array}{l}\text { Danışmanlık şirketlerinden } \\
\text { hizmet satın alır. }\end{array}$ & Zayıf (+) & $r_{\mathrm{s}}=, 317 \mathrm{n}=129, \mathrm{p}<, 01$ \\
\hline & Risk üstlenir. & İlişki yok & $r_{\mathrm{s}}=, 053 \mathrm{n}=129, \mathrm{p}=, 551>, 01$ \\
\hline \multirow{6}{*}{$\begin{array}{l}\text { İç piyasaya yönelik } \\
\text { üretim yapıyoruz. }\end{array}$} & Değişime açık biridir. & Zayıf (+) & $r_{\mathrm{s}}=, 202 \mathrm{n}=129, \mathrm{p}<, 05$ \\
\hline & Sık sık yurtdışına çıkar. & İlişki yok & $r_{\mathrm{s}}=, 116 \mathrm{n}=129, \mathrm{p}=, 189>, 01$ \\
\hline & Fuarlara katılır. & İlişki yok & $r_{\mathrm{s}}=, 028 \mathrm{n}=129, \mathrm{p}=, 749>, 01$ \\
\hline & $\begin{array}{l}\text { Eğitimlere ve seminerlere } \\
\text { katılır. }\end{array}$ & İliş̧ki yok & $r_{\mathrm{s}}=, 002 \mathrm{n}=129, \mathrm{p}=, 983>, 01$ \\
\hline & $\begin{array}{l}\text { Danışmanlık şirketlerinden } \\
\text { hizmet satın alır. }\end{array}$ & İliş̧ki yok & $r_{\mathrm{s}}=-, 010 \mathrm{n}=129, \mathrm{p}=, 914>, 01$ \\
\hline & Risk üstlenir. & İlişki yok & $r_{\mathrm{s}}=-, 060 \mathrm{n}=129, \mathrm{p}=, 497>, 01$ \\
\hline \multirow{6}{*}{$\begin{array}{l}\text { Mevcut üretim ve } \\
\text { satışlarımızdan } \\
\text { memnunuz. }\end{array}$} & Değişime açık biridir. & Zayıf (-) & $r_{\mathrm{s}}=-, 205 \mathrm{n}=129, \mathrm{p}<, 05$ \\
\hline & Sık sık yurtdışına çıkar. & İlişki yok & $r_{\mathrm{s}}=-, 144 \mathrm{n}=129, \mathrm{p}=, 103>, 01$ \\
\hline & Fuarlara katılır. & Zayıf (-) & $r_{\mathrm{s}}=-, 294 \mathrm{n}=129, \mathrm{p}<, 01$ \\
\hline & $\begin{array}{l}\text { Eğitimlere ve seminerlere } \\
\text { katılır. }\end{array}$ & Zayıf (-) & $r_{\mathrm{s}}=-, 315 \mathrm{n}=129, \mathrm{p}<, 01$ \\
\hline & $\begin{array}{l}\text { Danışmanlık şirketlerinden } \\
\text { hizmet satın alır. }\end{array}$ & Zayıf (-) & $r_{\mathrm{s}}=-, 362 \mathrm{n}=129, \mathrm{p}<, 01$ \\
\hline & Risk üstlenir. & Zayıf (-) & $r_{\mathrm{s}}=-, 219 \mathrm{n}=129, \mathrm{p}<, 01$ \\
\hline \multirow{6}{*}{$\begin{array}{l}\text { Yeterince büyük } \\
\text { değiliz. }\end{array}$} & Değişime açık biridir. & İlişki yok & $r_{\mathrm{s}}=, 102 \mathrm{n}=129, \mathrm{p}=, 251>, 01$ \\
\hline & S1k sık yurtdışına çıkar. & Zayıf (-) & $r_{\mathrm{s}}=-, 195 \mathrm{n}=129, \mathrm{p}<, 05$ \\
\hline & Fuarlara katılır. & İlişki yok & $r_{\mathrm{s}}=, 104 \mathrm{n}=129, \mathrm{p}=, 243>, 01$ \\
\hline & $\begin{array}{l}\text { Eğitimlere ve seminerlere } \\
\text { katılır. }\end{array}$ & İlişki yok & $r_{\mathrm{s}}=, 123 \mathrm{n}=129, \mathrm{p}=, 163>, 01$ \\
\hline & $\begin{array}{l}\text { Danışmanlık şirketlerinden } \\
\text { hizmet satın alır. }\end{array}$ & İliş̧ki yok & $r_{\mathrm{s}}=-, 082 \mathrm{n}=129, \mathrm{p}=, 353>, 01$ \\
\hline & Risk üstlenir. & Zayıf (-) & $r_{\mathrm{s}}=-, 197 \mathrm{n}=129, \mathrm{p}<, 05$ \\
\hline
\end{tabular}

İhracat yapmayan işletmelere sunulan, ihracat yapmama nedenlerini ifade ettiği düşünülen 5 neden ile girişimcinin 6 özelliği arasındaki ilişkiler analiz edilmiş ve Tablo 4'te sunulmuştur. "Süreçler konusunda bilgimiz yok" ifadesini kullanma düzeyi ile; girişimcinin değişime açık biri olduğunu ifade etme düzeyi arasında pozitif yönlü zayıf ilişki; eğitim-seminerlere katıldığını ifade etme düzeyi ve danışmanlık şirketlerinden hizmet satın aldığını belirtme düzeyi arasında pozitif yönlü çok zayıf ilişki bulunmaktadır. 
"Pazarlar konusundan bilgimiz yok" ifadesini kullanma düzeyi ile girişimcinin değişime açık biri olduğunu, sık sık yurtdışına çıktığını, eğitim ve seminerlere katıldığını ve danışmanlık şirketlerinden hizmet satın aldığını ifade etme düzeyleri arasında pozitif yönlü zayıf ilişki bulunmaktadir.

"İç piyasaya yönelik üretim yapıyoruz” ifadesini kullanma düzeyi ile girişimcinin değişime açık biri olduğunu ifade etme düzeyi arasında pozitif yönlü zayıf ilişki bulunmaktadır.

"Mevcut üretim ve satışlarımızdan memnunuz" ifadesini kullanma düzeyi ile girişimcinin değişime açık biri olduğunu, fuarlara katıldığını, eğitim ve seminerlere katıldığını, danışmanlık şirketlerinden hizmet satın aldığını ve risk üstlendiğini ifade etme düzeyi arasında negatif yönlü zayıf ilişki bulunmaktadır.

"Yeterince büyük değiliz" ifadesini kullanma düzeyi ile girişimcinin sık sık yurt dışına çıktığını ve risk üstlendiğini ifade etme düzeyleri arasında negatif yönlü zayıf ilişki bulunmaktadır.

Tablo 5: İşletmelerin İhracat Yapmama Nedenleri İle İhracat Algı Düzeyi Arasındaki İlişkiler

\begin{tabular}{|c|c|c|c|}
\hline $\begin{array}{l}\text { 1. Değişken } \\
\text { İhracat } \\
\text { Yapmama } \\
\text { Nedeni }\end{array}$ & $\begin{array}{l}\text { 2. Değişken } \\
\text { İhracat Algısı }\end{array}$ & $\begin{array}{l}\text { İlişkinin } \\
\text { Yönü ve } \\
\text { Kuvveti }\end{array}$ & $r_{s}, \mathbf{n}$ ve $p$ değerleri \\
\hline \multirow{5}{*}{$\begin{array}{l}\text { Süreçler } \\
\text { konusunda } \\
\text { bilgimiz yok. }\end{array}$} & İhracat yaparken risk yüksektir. & İlişki yok & $r_{\mathrm{s}}=, 099 \mathrm{n}=129, \mathrm{p}=, 262>, 01$ \\
\hline & İhracat yapmak için büyük sermaye gerekir. & Zayıf (+) & $r_{\mathrm{s}}=, 224 \mathrm{n}=129, \mathrm{p}<, 05$ \\
\hline & $\begin{array}{l}\text { İhracat yapmak için büyük ölçekli işletme } \\
\text { olmak gerekir. }\end{array}$ & İlişki yok & $r_{\mathrm{s}}=, 173 \mathrm{n}=129, \mathrm{p}=, 050>, 01$ \\
\hline & İhracat yapmak çok karlıdır. & İlişki yok & $r_{\mathrm{s}}=, 015 \mathrm{n}=129, \mathrm{p}=, 870>, 01$ \\
\hline & İhracat bir işletme için başarı göstergesidir. & İlişki yok & $r_{\mathrm{s}}=, 003 \mathrm{n}=129, \mathrm{p}=, 970>, 01$ \\
\hline \multirow{5}{*}{$\begin{array}{l}\text { Pazarlar } \\
\text { konusunda } \\
\text { bilgimiz yok. }\end{array}$} & İhracat yaparken risk yüksektir. & İlişki yok & $r_{\mathrm{s}}=, 147 \mathrm{n}=129, \mathrm{p}=, 096>, 01$ \\
\hline & İhracat yapmak için büyük sermaye gerekir. & İlişki yok & $r_{\mathrm{s}}=, 136 \mathrm{n}=129, \mathrm{p}=, 126>, 01$ \\
\hline & $\begin{array}{l}\text { İhracat yapmak için büyük ölçekli işletme } \\
\text { olmak gerekir. }\end{array}$ & Zayıf (+) & $r_{\mathrm{s}}=, 286 \mathrm{n}=129, \mathrm{p}<, 01$ \\
\hline & İhracat yapmak çok karlıdır. & İlişki yok & $r_{\mathrm{s}}=, 064 \mathrm{n}=129, \mathrm{p}=, 474>, 01$ \\
\hline & İhracat bir işletme için başarı göstergesidir. & İlișki yok & $r_{\mathrm{s}}=-136 \mathrm{n}=129, \mathrm{p}=, 264>, 01$ \\
\hline \multirow{5}{*}{$\begin{array}{l}\text { İç piyasaya } \\
\text { yönelik üretim } \\
\text { yapıyoruz. }\end{array}$} & İhracat yaparken risk yüksektir. & İlişki yok & $r_{\mathrm{s}}=-, 029 \mathrm{n}=129, \mathrm{p}=, 745>, 01$ \\
\hline & İhracat yapmak için büyük sermaye gerekir. & İlişki yok & $r_{\mathrm{s}}=, 120 \mathrm{n}=129, \mathrm{p}=, 176>, 01$ \\
\hline & $\begin{array}{l}\text { İhracat yapmak için büyük ölçekli işletme } \\
\text { olmak gerekir. }\end{array}$ & İlişki yok & $r_{\mathrm{s}}=, 123 \mathrm{n}=129, \mathrm{p}=, 164>, 01$ \\
\hline & İhracat yapmak çok karlıdır. & İlişki yok & $r_{\mathrm{s}}=, 057 \mathrm{n}=129, \mathrm{p}=, 521>, 01$ \\
\hline & İhracat bir işletme için başarı göstergesidir. & İlişki yok & $r_{\mathrm{s}}=-, 053 \mathrm{n}=129, \mathrm{p}=, 549>, 01$ \\
\hline \multirow{5}{*}{$\begin{array}{l}\text { Mevcut üretim } \\
\text { ve } \\
\text { satışlarımızdan } \\
\text { memnunuz. }\end{array}$} & İhracat yaparken risk yüksektir. & İlişki yok & $r_{\mathrm{s}}=-, 132 \mathrm{n}=129, \mathrm{p}=, 135>, 01$ \\
\hline & İhracat yapmak için büyük sermaye gerekir. & İlişki yok & $r_{\mathrm{s}}=-, 085 \mathrm{n}=129, \mathrm{p}=, 338>, 01$ \\
\hline & $\begin{array}{l}\text { İhracat yapmak için büyük ölçekli işletme } \\
\text { olmak gerekir. }\end{array}$ & İlişki yok & $r_{\mathrm{s}}=-, 042 \mathrm{n}=129, \mathrm{p}=, 638>, 01$ \\
\hline & İhracat yapmak çok karlıdır. & İlişki yok & $r_{\mathrm{s}}=, 026 \mathrm{n}=129, \mathrm{p}=, 770>, 01$ \\
\hline & İhracat bir işletme için başarı göstergesidir. & İlişki yok & $r_{\mathrm{s}}=, 090 \mathrm{n}=129, \mathrm{p}=, 331>, 01$ \\
\hline \multirow{5}{*}{$\begin{array}{l}\text { Yeterince } \\
\text { büyük değiliz. }\end{array}$} & İhracat yaparken risk yüksektir. & İlişki yok & $r_{\mathrm{s}}=-, 026 \mathrm{n}=129, \mathrm{p}=, 770>, 01$ \\
\hline & İhracat yapmak için büyük sermaye gerekir. & İlişki yok & $r_{\mathrm{s}}=, 140 \mathrm{n}=129, \mathrm{p}=, 114>, 01$ \\
\hline & $\begin{array}{l}\text { İhracat yapmak için büyük ölçekli işletme } \\
\text { olmak gerekir. }\end{array}$ & İlişki yok & $r_{\mathrm{s}}=-, 098 \mathrm{n}=129, \mathrm{p}=, 268>, 01$ \\
\hline & İhracat yapmak çok karlıdır. & İlişki yok & $r_{\mathrm{s}}=-, 159 \mathrm{n}=129, \mathrm{p}=, 072>, 01$ \\
\hline & İhracat bir işletme için başarı göstergesidir. & İlişki yok & $r_{\mathrm{s}}=, 124 \mathrm{n}=129, \mathrm{p}=, 160>, 01$ \\
\hline
\end{tabular}

İhracat yapmayan işletmelere sunulan, ihracat yapmama nedenlerini ifade ettiği düşünülen 5 neden ile ihracat algı düzeyi konusunda sunulan 5 ifade arasındaki ilişkiler analiz edilmiş ve Tablo 5 'te sunulmuştur. İhracat yapmama nedenlerini ifade ettiği düşünülen 5 nedenden sadece 
2'si ile ihracat alg1 düzeyi konusunda sunulan 5 ifadenin 2'si arasında ilişki bulunmuştur. 'Süreçler konusunda bilgimiz yok" ifadesini kullanma düzeyleri ile "ihracat yaparken büyük sermaye gerekir" algısı arasında pozitif yönlü zayıf ilişki bulunmaktadır. Benzer ş̧ekilde "pazarlar konusunda bilgimiz yok" ifadesini kullanma düzeyleri ile ihracat yapmak için büyük ölçekli işletme olmak gerekir algısı arasında pozitif yönlü zayıf ilişki bulunmaktadır.

Tablo 6: İşletmelerin İhracat Yapma Nedenleri ile Girişimcinin Özellikleri Arasındaki İlişkiler

\begin{tabular}{|c|c|c|c|}
\hline $\begin{array}{l}\text { 1. Değişken } \\
\text { İhracat Yapma } \\
\text { Nedeni }\end{array}$ & $\begin{array}{l}\text { 2. Değişken } \\
\text { Girişimci Özellikleri }\end{array}$ & $\begin{array}{l}\text { İlişsinin Yönü } \\
\text { ve Kuvveti }\end{array}$ & $r_{s}$, n ve $p$ değerleri \\
\hline \multirow{6}{*}{$\begin{array}{l}\text { İç piyasadaki } \\
\text { olumsuzluklar }\end{array}$} & Değişime açık biridir. & İlişki yok & $r_{\mathrm{s}}=-, 026 \mathrm{n}=117, \mathrm{p}=, 782>, 01$ \\
\hline & Sık sık yurtdışına çıkar. & İlişki yok & $r_{\mathrm{s}}=-, 023 \mathrm{n}=117, \mathrm{p}=, 802>, 01$ \\
\hline & Fuarlara katılır. & İlişki yok & $r_{\mathrm{s}}=-, 076 \mathrm{n}=117, \mathrm{p}=, 416>, 01$ \\
\hline & Eğitimlere ve seminerlere katılır. & İlişki yok & $r_{\mathrm{s}}=, 141 \mathrm{n}=117, \mathrm{p}=, 130>, 01$ \\
\hline & $\begin{array}{l}\text { Danışmanlık şirketlerinden hizmet } \\
\text { satın alır. }\end{array}$ & İlişski yok & $r_{\mathrm{s}}=, 041 \mathrm{n}=117, \mathrm{p}=, 657>, 01$ \\
\hline & Risk üstlenir. & İlişki yok & $r_{\mathrm{s}}=-, 026 \mathrm{n}=117, \mathrm{p}=, 777>, 01$ \\
\hline \multirow{6}{*}{$\begin{array}{l}\text { Piyasada ihracat } \\
\text { çok yaygın biz } \\
\text { de yapmak } \\
\text { istedik }\end{array}$} & Değişime açık biridir. & İlişki yok & $r_{\mathrm{s}}=-, 062 \mathrm{n}=117, \mathrm{p}=, 777>, 01$ \\
\hline & Sik sık yurtdışına çıkar. & İlişki yok & $r_{\mathrm{s}}=, 029 \mathrm{n}=117, \mathrm{p}=, 753>, 01$ \\
\hline & Fuarlara katılır. & İlişki yok & $r_{\mathrm{s}}=, 049 \mathrm{n}=117, \mathrm{p}=, 601>, 01$ \\
\hline & Eğitimlere ve seminerlere katılır. & Zayif $(+)$ & $r_{\mathrm{s}}=, 237 \mathrm{n}=117, \mathrm{p}<, 05$ \\
\hline & $\begin{array}{l}\text { Danışmanlık şirketlerinden hizmet } \\
\text { satın alır. }\end{array}$ & İlişki yok & $r_{\mathrm{s}}=, 093 \mathrm{n}=117, \mathrm{p}=, 321>, 01$ \\
\hline & Risk üstlenir. & İlişski yok & $r_{\mathrm{s}}=, 065 \mathrm{n}=117, \mathrm{p}=, 487>, 01$ \\
\hline \multirow{6}{*}{$\begin{array}{l}\text { Kazanç çok } \\
\text { yüksek }\end{array}$} & Değişime açık biridir. & Zayıf (+) & $r_{\mathrm{s}}=, 237 \mathrm{n}=117, \mathrm{p}<, 05$ \\
\hline & Sik sık yurtdışına çıkar. & İlişki yok & $r_{\mathrm{s}}=, 120 \mathrm{n}=117, \mathrm{p}=, 199>, 01$ \\
\hline & Fuarlara katılır. & İlişski yok & $r_{\mathrm{s}}=, 173 \mathrm{n}=117, \mathrm{p}=, 062>, 01$ \\
\hline & Eğitimlere ve seminerlere katılır. & İlişki yok & $r_{\mathrm{s}}=, 113 \mathrm{n}=117, \mathrm{p}=, 227>, 01$ \\
\hline & $\begin{array}{l}\text { Danışmanlık şirketlerinden hizmet } \\
\text { satın alır. }\end{array}$ & İlişsi yok & $r_{\mathrm{s}}=-, 005 \mathrm{n}=117, \mathrm{p}=, 953>, 01$ \\
\hline & Risk üstlenir. & İlişski yok & $r_{\mathrm{s}}=, 176 \mathrm{n}=117, \mathrm{p}=, 057>, 01$ \\
\hline \multirow{6}{*}{$\begin{array}{l}\text { İç talepten daha } \\
\text { fazla üretim } \\
\text { kapasitesine } \\
\text { sahibiz }\end{array}$} & Değişime açık biridir. & Zayıf (+) & $r_{\mathrm{s}}=, 184 \mathrm{n}=117, \mathrm{p}<, 05$ \\
\hline & Sik sık yurtdışına çıkar. & Zayif (+) & $r_{\mathrm{s}}=, 221 \mathrm{n}=117, \mathrm{p}<, 05$ \\
\hline & Fuarlara katılır. & İlişki yok & $r_{\mathrm{s}}=, 114 \mathrm{n}=117, \mathrm{p}=, 220>, 01$ \\
\hline & Eğitimlere ve seminerlere katılır. & Zayıf (+) & $r_{\mathrm{s}}=, 220 \mathrm{n}=117, \mathrm{p}<, 05$ \\
\hline & $\begin{array}{l}\text { Danışmanlık şirketlerinden hizmet } \\
\text { satın alır. }\end{array}$ & İlişski yok & $r_{\mathrm{s}}=, 117 \mathrm{n}=117, \mathrm{p}=, 208>, 01$ \\
\hline & Risk üstlenir. & Zayıf (+) & $r_{\mathrm{s}}=, 270 \mathrm{n}=117, \mathrm{p}<, 01$ \\
\hline \multirow{5}{*}{$\begin{array}{l}\text { Yurtdışında } \\
\text { pazar } \\
\text { fursatlarının } \\
\text { mevcudiyeti }\end{array}$} & Değişime açık biridir. & İlişki yok & $r_{\mathrm{s}}=, 157 \mathrm{n}=117, \mathrm{p}=, 091>, 01$ \\
\hline & Sik sık yurtdışına çıkar. & Çok zayıf $(+)$ & $r_{\mathrm{s}}=, 196 \mathrm{n}=117, \mathrm{p}<, 05$ \\
\hline & Fuarlara katılır. & Zayif (+) & $r_{\mathrm{s}}=, 251 \mathrm{n}=117, \mathrm{p}<, 01$ \\
\hline & Eğitimlere ve seminerlere katılır. & İlişki yok & $r_{\mathrm{s}}=, 096 \mathrm{n}=117, \mathrm{p}=, 304>, 01$ \\
\hline & $\begin{array}{l}\text { Danışmanlık şirketlerinden hizmet } \\
\text { satın alır. }\end{array}$ & İlişki yok & $r_{\mathrm{s}}=, 159 \mathrm{n}=117, \mathrm{p}=, 086>, 01$ \\
\hline
\end{tabular}

İhracat yapan işletmelere sunulan, ihracat yapma nedenlerini ifade ettiği düşünülen 5 neden ile girişimcinin 6 özelliği arasındaki ilişkiler analiz edilmiş ve Tablo 6 'da sunulmuştur.

"Piyasada ihracat çok yaygın olduğu için biz de ihracat yapmak istedik" ifadesini kullanma düzeyi ile girişimcinin eğitim ve seminerlere katıldığını ifade etme düzeyi arasında pozitif yönlü zayıf ilişki bulunmaktadır.

"Kazanç çok yüksek" ifadesini kullanma düzeyi ile girişimcinin değişime açık biri olduğunu ifade etme düzeyi arasında pozitif yönlü zayıf ilişki bulunmaktadır. 
"İç talepten daha fazla üretim kapasitesine sahibiz" ifadesini kullanma düzeyi ile girişimcinin değişime açık biri olduğunu, sık yurtdışına çıktığını, eğitim ve seminerlere katıldığını ve risk üstlendiğini ifade etme düzeyleri arasında pozitif yönlü zayıf ilişki bulunmaktadır.

"Yurtdışında pazar firsatlarının mevcudiyeti" ifadesini kullanma düzeyi ile girişimcinin sık yurtdışına çıktığını ifade etme düzeyi arasında pozitif yönlü çok zayıf ilişki; ve fuarlara katıldığını ifade etme düzeyi arasında pozitif yönlü zayıf ilişki bulunmaktadır.

\section{Sonuç ve Öneriler}

Türkiye ihracata dayalı bir büyüme modeli benimsediği için ihracat çokça çalışılan bir konudur. Ancak gerçekleştirilen uygulamalı çalışmalar içinde ihracat karar sürecinin daha az incelenen bir konu olarak kaldığ 1 görülmektedir. Bu çalışmanın amacı, girişimcinin kişisel özelliklerinin ihracat kararı üzerindeki etkisini araştırmaktır. Çalışmada, ihracat yapan ve yapmayan işletmeler arasında, girişimcinin çeşitli özellikleri ve ihracat konusunda algı düzeyini ifade eden çeşitli değişkenler açısından fark bulunma durumu araştııılmıştır. Ayrıca ihracat oranı, girişimcinin çeşitli özellikleri, işletmelerin ihracat yapma/yapmama nedenleri ve ihracat algı düzeyi arasındaki ilişkiler incelenmiştir. Araştırma, işletme düzeyinde ihracat karar sürecinin daha iyi anlaşılmasına katkıda bulunmayı amaçlamaktadır.

İhracat yapan ve yapmayan işletmeler arasında, ihracat yapmak için büyük ölçekli işletme olmak gerekir ve büyük sermaye gerekir ifadelerinde istatistiksel olarak anlamlı bir farkl1lık bulunmaktadır. İhracat yapmayan işletmeler, ihracat yapan işletmelere kıyasla, ihracat yapmak için büyük sermaye gerekir ve büyük ölçekli işletme olmak gerekir ifadelerine, daha yüksek düzeylerde cevap vermiştir. İhracat yaparken risk yüksektir, ihracat yapmak çok karlıdır ve ihracat bir işletme için başarı göstergesidir ifadeleri için iki grup arasında istatistiki olarak anlamlı bir farklılık bulunmamıştır.

İhracat yapan ve yapmayan işletmeler arasında, girişimcinin 3 özelliği açısından istatistiksel olarak anlamlı farklılık bulunmuştur. İhracat yapan işletmelerin girişimcileri, yapmayanlara kıyasla daha yüksek ortalamalarla sık s1k yurt dışına çıkmakta, fuarlara katılmakta ve risk üstlenmektedir. Araştırma sonuçları ilgili yazını desteklemektedir (Brooks ve Rosson, 1982; Denis ve Depelteau, 1985; Cavusgil ve Naor, 1987; Dichtl vd., 1990; Davidsson, 1991; Daniele, 1994; Koçak, 1997; Bernard ve Wagner, 1997; Bernard ve Jensen, 1999; Danışman ve Sökmen, 2007).

Diğer yandan iki grup arasında girişimcinin 3 özelliği açısından istatistiksel olarak anlamlı farklılık bulunmamıştır. İhracat yapan ve yapmayan işletmelerin girişimcileri, benzer düzeylerde değişime açıktır, eğitim ve seminerlere katılır ve danışmanlık şirketlerinden hizmet satın alırlar. Bu sonuç iki şekilde yorumlanabilir. Örneklem içindeki işletmelerin faaliyetleri içinde eğitim ve seminerlere katılım ve danışmanlık şirketlerinden hizmet satın alımının ihracat faaliyeti ile ilgili olmadığı düşünülebilir. Diğer yandan, söz konusu iki faaliyetin yurtdışı pazar araştırması ve ihracat işlemleri konusunda teknik/bürokratik süreçler konusunda destek olarak değerlendirilmesi durumunda araştırma sonuçları ilgili yazını desteklemeyen bir sonuç ortaya koymaktadır. İhracat karar süreci konusunda yazında bilgi toplama süreçlerinin ihracat kararını olumlu etkilediği ifade edilmektedir (Johanson ve Weidersheim-Paul, 1975; Cavusgil, 1980; Sood ve Adams, 1984; Cavusgil ve Naor, 1987; Koçak, 1997; Danışman ve Sökmen, 2007). Ancak işletmenin ihracat kararını verdiği ve/veya ilk işlemlerini gerçekleştirdiği süreç içinde bu bilgi ve desteğe ihtiyaç duyacağı; ilerleyen işlemlerde, kazandığı tecrübe ve kurumsal sermayesi ile dışardan desteğe ihtiyacı kalmayacağı değerlendirilmektedir. Özellikle işletmenin ölçeği büyüdükçe ihracat işlemlerinin gerçekleştirildiği departmanlar bulunabileceği göz ardı edilmemelidir.

Analiz sonuçları bir arada değerlendirildiğinde ihracat yapan ve yapmayan işletmeler arasındaki farklılıklar şu şekilde özetlenebilir: İhracat yapmayan işletmelerin, ihracat yapanlara kıyasla, daha yüksek düzeyde ihracat yapmak için büyük ölçekli işletme olmak gerektiği 
düşüncesine sahip oldukları, daha az sıklıkla yurtdışına çıktıkları, daha az fuarlara katıldıkları ve daha az risk üstlendikleri görülmektedir.

İhracat oranı ile girişimcinin 4 özelliği- değişime açık biridir, sık sık yurt dışına çıkar, fuarlara katılır ve risk üstlenir ifadeleri- arasında pozitif yönlü çok zayıf ilişki bulunmaktadır. Girişimcinin değişime açık, sıklıkla yurtdışına çıkan, fuarlar katılan ve risk üstlenen bir kişi olduğu konusunda ifade düzeyi artıkça ihracat oranı artmaktadır. Bu sonuç ilgili yazını desteklemektedir (Bilkey ve Tesar, 1977; Koh, 1991; Thompson, 1999). İhracat oranı ile girişimcinin 2 özelliğieğitim ve seminerlere katılır ve danışmanlık şirketlerinden hizmet satın alır- arasında istatistiksel olarak anlamlı bir ilişki bulunmamıştır.

İhracat yapmayan işletmelere sunulan, ihracat yapmama nedenlerini ifade ettiği düşünülen 5 neden ile girişimcinin 6 özelliği arasındaki ilişkiler analiz edilmiştir. Bulunan ilişkiler zayıf veya çok zayıf niteliktedir: Süreçler konusunda bilgisi olmadığını ifade eden işletmelerde girişimciler daha çok değişime açıktır, daha çok eğitim ve seminerlere katılmakta ve danışmanlık şirketlerinden hizmet satın almaktadır. Pazarlar konusundan bilgisi olmadığını ifade eden işletmelerde girişimciler, daha çok değişime açıktır, daha çok sıklıkla yurtdışına çıkmaktadır, daha çok eğitim ve seminerlere katılmakta ve danışmanlık şirketlerinden hizmet satın almaktadır. İç piyasaya yönelik üretim yaptığını ifade eden işletmelerde girişimcilerin daha çok değişime açık oldukları kaydedilmiştir. Mevcut üretim ve satışlarından memnun olduklarını ifade eden işletmelerde girişimcilerin daha az değişime açık oldukları, fuarlara, eğitim ve seminerlere da az katıldıkları, danışmanlık şirketlerinden daha az hizmet satın aldıkları ve daha az risk üstlendikleri görülmektedir. Yeterince büyük olmadıklarını ifade eden işletmelerde girişimcilerin daha az sıklıkla yurtdışına çıktıkları ve daha az risk üstlendikleri görülmektedir.

Değişkenler arasındaki ilişkiler bir arada değerlendirildiğinde ihracat yapmama nedenleri ile girişimcilerin özellikleri arasındaki ilişkilerin, işletmelere ilişkin gruplandırma firsatı verdiği düşünülmektedir: Süreçler ve pazarlar konusunda bilgisi olmadığını ifade eden işletmelerin ihracata yönlendirilebilecek bir grubu temsil ettiği değerlendirilmektedir. Girişimciler değişime açık, eğitim ve seminerlere katılan, danışmanlık hizmetleri satın alan kişilerdir. İhracat kararını olumlu yönde etkileyebilecek bilgi toplama ve destek sağlama süreci içinde oldukları düşünülebilir ve/veya söz konusu faaliyetler eğer ihracat ile ilgili değilse bu işletmelerin, ihracata yönelik eğitim, seminer ve danışmanlık hizmetleri alması özendirilebilir. İç piyasaya yönelik üretim yaptığını ifade eden işletmelerde ihracat yapmamanın bir pazar tercihi olduğu değerlendirilmektedir. Girişimcilerin değişime açı olduğu, diğer özellikler açısından da değişkenler arasında herhangi bir negatif yönlü ilişki olmadığı görülmektedir. Mevcut üretim ve satışlarından memnun olduklarını ifade eden işletmelerin daha kapalı bir işletme grubunu temsil ettiği görülmektedir. Sunulan 6 girişimci özelliğinin 5'inde negatif yönlü ilişkiler tespit edilmiştir. Yeterince büyük olmadıkları için ihracat yapmadıklarını ifade eden işletmelerin önyargılı bir işletme grubunu temsil ettiği değerlendirilmektedir. Girişimcilerin yurtdışına çıkışının özendirilmesinin bu önyargının ortadan kaldırılmasına katkı sağlayabileceği düşünülmektedir.

İhracat yapmayan işletmelere sunulan ihracat yapmama nedenlerini ifade ettiği düşünülen 5 nedenden sadece 2'si ile ihracat algı düzeyi konusunda sunulan 5 ifadenin 2'si arasında ilişki bulunmuştur. Süreçler konusunda bilgisi olmadığını ifade eden işletmelerde, daha yüksek düzeylerde, ihracat yaparken büyük sermaye gerektiği ifadesi kullanılmıştır. Benzer şekilde pazarlar konusunda bilgisi olmayan işletmelerde, daha yüksek düzeylerde, ihracat yapmak için büyük ölçekli işletme olmak gerektiği ifadesi kullanılmıştır. Süreçler ve pazarlar konusunda bilgisi olmadığı için ihracat yapmadığını ifade eden işletmelerde ihracat yapmak için büyük ölçekli işletme olmak gerekir algısının daha kuvvetli olduğu görülmektedir. Söz konusu işletmelerin bilgi sahibi olmadıkları için bir önyargıya sahip oldukları değerlendirilmektedir. Diğer yandan ihracat yapmama nedenleri ile ihracat algı düzeyi değişkenleri arasında toplam 25 değişken arasında ilişki araştırılmış ve sadece bu 2 ilişki tespit edilmiştir. İşletmelerin neden ihracat yapmadıklarını ifade 
eden değişkenlerden bilgi eksikliğini işaret eden 2 değişkenin işletme ölçeğinin büyük olmas1 gerektiği yönündeki 2 önyargı ile zayıf ilişkili olduğu; tüm ihracat yapmama nedenlerinin, ihracatın karlı olduğu, riskli olduğu ve başarı göstergesi olduğunu ifade eden değişkenler ile ilişkisiz olduğu görülmektedir.

İhracat yapan işletmelere sunulan, ihracat yapma nedenlerini ifade ettiği düşünülen 5 neden ile girişimcinin 6 özelliği arasındaki ilişkiler analiz edilmiştir. Piyasada ihracat çok yaygın olduğu için ihracat yaptıklarını ifade eden işletmelerde girişimciler eğitim ve seminerlere daha çok katılmaktadır. Kazancın yüksekliği nedeniyle ihracat yaptıklarını ifade eden işletmelerde girişimcilerin daha çok değişime açık oldukları belirtilmiştir. İç talepten daha fazla üretim kapasitesine sahip oldukları için ihracat yaptıklarını ifade eden işletmelerde girişimciler, daha çok değişime açıktır; daha sıklıkla yurtdışına çıktıkları, daha çok eğitim ve seminerlere katıldıkları ve daha çok risk üstlendikleri görülmektedir. Yurtdışında pazar firsatlarının mevcudiyeti nedeniyle ihracat yapan işletmelerde girişimcilerin daha sıklıkla yurtdışına çıktıkları ve daha çok fuarlara katıldıkları belirtilmiştir.

İhracat yapmak için büyük ölçekli işletme olmak gerekir ve büyük sermaye gerekir ifadelerinin, hem ihracat yapan ve yapmayan işletmeler arasındaki farklılıklarda ortaya çıktığı, hem de ihracat yapmama nedenleri içinde "süreçler konusunda ve pazarlar konusunda bilgimiz yok" ifadesi ile pozitif yönlü ilişki içinde olduğu tespit edilmiştir. İki sonuç birlikte ele alındığında, bir önyarg1 ortaya koyduğu değerlendirilmektedir. İhracat yapan küçük ve orta ölçekli işletmelerin başarılarının; ticaret ve sanayi odaları, ihracatçı birlikleri ve üretici birlikleri gibi kuruluşlar tarafından daha çok ve sıklıkla paylaşılmasının, bu önyargının kırılmasına katkıda bulunacağı ve ihracat karar sürecindeki işletmeleri cesaretlendireceği düşünülmektedir.

Türkiye'de ihracat üzerine çok çalışma yapılmış olmasına rağmen ihracat karar süreci daha az incelenen bir konu olarak kalmıştır. Endüstri-spesifik ihracat girişimciliğini konu alan çalışmaların ilgili endüstride ihracatın arttırılması için uygun teşvik/müdahale araçlarının tasarlanması ve kullanılmasına imkan sağlayacağı düşünülmektedir. Benzer şekilde dezavantajlı bölgelerde ihracat girişimciliğinin araştırılması, yerel ekonomik kalkınmayı destekleyecek bir ihracat performansına ulaşmak isteyen bölgelerde yeni politika araçlarının tasarlanması ve uygulanmasına katkıda bulunacaktır. Bu bağlamda endüstri-spesifik ve bölgesel düzeyde ihracat karar sürecini araştıran, ihracat yapan ve yapmayan işletmeler arasındaki farklılıkları ortaya koyan yeni çalışmaların yapılması önerilmektedir.

\section{Kaynakça}

Aaby, N.E., \& Slater, S.F. (1988). Management influences on export performance: A review of the empirical literature 1977-1988. International Marketing Review, 6(4), 7-25.

Acılar, A., Hatipoğlu, C., \& Bingöl, H. (2015). The reasons for enterprises of not doing export facilities: case of Bilecik province. 4-5 Haziran 2015 Global Business Research Congress, İstanbul, 308-317.

Ağan, Y., \& Erdoğan, E. (2016). The perception of export barriers by Turkish manufacturing firms. Finans Politik ve Ekonomik Yorumlar, 53(614).

Aktürk, A., \& Şenol, H. (2010). KOBİ'ler açısından ihracat teşviklerinin önemi ve etkinliğinin arttırılmasına yönelik öneriler. Süleyman Demirel Üniversitesi İktisadi ve İdari Bilimler Fakültesi Dergisi, 15(2), 375-391.

Andersen, O. (1993). On the internationalization process of firms: a critical analysis. Journal of $\begin{array}{llll}\text { International Business 209-231. } & \text { Studies, }\end{array}$ https://doi.org/10.1057/palgrave.jibs.8490230 
Bas, M. (2012). Input-trade liberalization and firm export decisions: evidence from Argentina. Journal of Development Economics, 97(2), 481-493. https://doi.org/10.1016/j.jdeveco.2011.05.010

Beamish, P.W., \& Dhanaraj, C. (2003). A resource-based approach to the study of export performance. Journal of Small Business Management, 41(3), 242-261.

Bernard, A.B., \& Jensen, J.B. (1999). Exceptional exporter performance: cause, effect or both? Journal of International Economics, 47(1), 1-25.

Bernard, A.B., \& Wagner, J. (1997). Exports and success in German manufacturing. Review of World Economics, 133(1), 134-157.

Bilkey, W.J., \& Tesar, G. (1977). The export behavior of smaller-sized Wisconsin manufacturing firms. Journal of International Business Studies, 8(1), 93- 98.

Braymen, C., Briggs, K., \& Boulware, J. (2011). R\&D and the export decision of new firms. Southern Economic Journal, 78(1), 191-210.

Brooks, M. R., \& Rosson, P. J. (1982). A study of export behavior of small and medium sized manufacturing firms in three Canadian provinces. New York: Praegar, 39-54.

Cavusgil, S.T. (1980). On the internationalization process of firms. European Research, 8(6), 273281.

Cavusgil, S.T., \& Naor, J. (1987). Firm and management characteristics as discriminators of export marketing activity. Journal of Business Research, 15(3), 221-235.

Cavusgil, S.T., \& Nevin, J. R. (1981). Internal determinants of export marketing behavior: An empirical investigation. Journal of Marketing Research, 18(1), 155.

Chen, M.X., Wilson, J.S., \& Otsuki, T. (2008). Standards and export decisions: firm-level evidence from developing countries. The Journal of International Trade \& Economic Development, 17(4), 501-523. http://dx.doi.org/10.1080/09638190802250027

Co, C.Y., Nguyen, T.K., Nguyen, T.N., \& Tran, Q.N. (2018). The exporting and subcontracting decisions of Viet Nam's small- and medium-sized enterprises. International Review of Economics \& Finance. https://doi.org/10.1016/j.iref.2018.05.004

Çetin, K. (2016). Inovasyonun İhracat Performansına Etkisi: Karaman İli Örneği. (Yüksek Lisans Tezi). KTO Karatay Üniversitesi, Sosyal Bilimler Enstitüsü, Konya.

Çoban, S. (2005). Kayseri mobilya sanayinin dış ticaret yapısı ve sorunlarına yönelik bir araştırma. Selçuk Üniversitesi Karaman İktisadi ve İdari Bilimler Dergisi, 5(2), 73-82.

Çütcü, İ. (2013). İhracatçı firmaların kalkınmaya etkisi ve firmaların ihracat performansını etkileyen faktörler: Güneydoğu Anadolu Bölgesi üzerine bir uygulama. Adiyaman Üniversitesi Sosyal Bilimler Enstitüsü Dergisi, 6(15), 151-184.

Çütcü, İ., \& Cenger, H. (2017). Türkiye'de dış ticaret ve işsizlik arasındaki ilişki: yapısal kırılmalı zaman serisi analizi. III. Uluslararası Girişimcilik, Istihdam ve Kariyer Kongresi Bildiriler Kitabl, 68-82.

Daniele, D. (1994). The exporting process: The evolution of small and medium sized firms. Advances in International Marketing, 6, 32-42.

Danışman, A., \& Sökmen, A. G. (2007). Girişimcilik özellikleri ve firma niteliklerinin ihracat performansına etkisi: KOBI'ler üzerine bir araştırma. Ç. Ü. Sosyal Bilimler Enstitüsü Dergisi, 16(1), 213-230. 
Das, M. (1994). Successful and unsuccessful exports from developing countries, some preliminary findings. European Journal of Marketing, 28(12), 19-33.

Davidsson, P. (1991). Continued entrepreneurship: ability, need and opportunity as determinants for small firm growth. Journal of Business Venturing, 6, 405-429.

Denis, J.E., \& Depelteau, D. (1985). Market knowledge, diversification and export expansion. Journal of International Business Studies, 16(3), 77-89.

Dichtl, E.H., Koeglmayr, G.H., \& Mueller, S. (1990). International orientation as a precondition or export success. Journal of International Business Studies, 21(1), 23-41.

Doğanlar, M., Bal, H., \& Özmen, M. (2003). Uluslararası ticaret ve Türkiye'nin ihracat fonksiyonu. Manas Journal of Social Studies, 4(7), 83-109.

Durman, M., Koyuncu, C., \& Önder, H. (2007). İhracat teşviklerinden yararlanmayı etkileyen faktörler. Süleyman Demirel Üniversitesi İktisadi ve İdari Bilimler Fakültesi Dergisi, 12(2), 121-134.

Durmuş, B., Yurtkoru, E.S., \& Çinko, M. (2013). Sosyal Bilimlerde SPSS'le Veri Analizi. İstanbul: Beta Yayınevi.

Ersungur, Ş. M., \& Takım, A. (2018). Türkiye'de teşvik sisteminin yapısı, sorunları ve etkinliği üzerine bir politika önerisi: tek bir uygulamacı kuruluş sorunları çözer mi? Atatürk Üniversitesi İktisadi ve İdari Bilimler Dergisi, 32(3), 725-744.

Ersungur, Ş.M. \& Yalman, İ.N. (2009). Bölgesel kalkınmada ihracat teşviklerinin etkinliği: Sivas ilinde bir uygulama. C. Ü. Íktisadi ve İdari Bilimler Dergisi, 10(1), 81-98.

Gediz, B., \&Yalçınkaya, H. (2004). Türkiye'de ihracat projeksiyonu. Yönetim ve Ekonomi, 11(1), $35-55$.

Gozgor, G., \& Piskin, A. (2011). İşsizlik ve diş ticaret: Türkiye'deki bölgeler için genelleştirilmiş momentler yöntemi-dinamik panel veri yaklaşımı. Business and Economics Research Journal, 2(3), 121-138.

Greenaway, D., Guariglia, A., \& Kneller, R. (2007). Financial factors and exporting decisions. Journal of International Economics, 73(2), 377-395. https://doi.org/10.1016/j.jinteco.2007.04.002

He, X., \& Wei, Y. (2013). Export market location decision and performance: the role of external networks and absorptive capacity. International Marketing Review, 30(6), 559-590.

Ibeh, K. I., \& Young, S. (2001). Exporting as an entrepreneurial act- an empirical study of Nigerian firms. European Journal of Marketing, 35(5-6), 566-586.

Inui, T., Ito, K., \& Miyakawa, D. (2015). Overseas market information and firms' export decisions. Economic Inquiry, 53(3), 1671-1688.

İnan, H., \& Nakıboğlu, B. (2009). KOBİlerin ihracatta karşılaştıkları engellerin belirlenmesine yönelik mobilya sektöründe gerçekleştirilen bir araştırma. Ç. Ü. Sosyal Bilimler Enstitüsü Dergisi, 18(2), 228-246.

Johanson, J., \& Wiedersheim-Paul, F. (1975). The internationalization of the firm: four Swedish cases. Journal of Management Studies, October, 305-322.

Kahveci, E. (2012). İşletme stratejileri ve ihracat performansı ilişkileri. Akademik Araştırmalar ve Çalışmalar Dergisi, 4(6), 2-34. 
Kahveci, E. (2013). İhracat performansı ölçütleri ve ihracat performansını etkileyen faktörler. Verimlilik Dergisi, 1, 43-74.

Kammath, S., Rosson, P.J., Patton, D., \& Brooks, M. (1989). Research on success in exporting: past, present and future. Ed. P.J. Rosson, \& S.D. Reid. Managing Export Entry and Expansion. Praegar: New York, 398-421.

Kapri, K. (2018). Impact of political instability on firm-level export decisions. International Review of Economics and Finance. https://doi.org/10.1016/j.iref.2018.08.008

Kılıç, S. (2007). Küçük ve orta ölçekli işletmelerin ihracat pazarlaması davranışını etkileyen faktörler ile ihracat performansı arasındaki ilişkilere dair ampirik bir çalışma: Çorum makine imalat sanayi örneği. Çukurova Üniversitesi İ̈BF Dergisi, 11(1), 40-62.

Koçak, F.A. (1997). Bir ihracat karar süreci modeli denemesi. Ankara Üniversitesi Siyasal Bilgiler Fakültesi Dergisi, 52(1-4), 467-490.

Koenig, P. (2009). Agglomeration and the export decisions of French firms. Journal of Urban Economics, 66(3), 186-195.

Koh, A.C. (1991). Relationships among organizational characteristics, marketing strategy and export performance. International Marketing Review, 8(3), 46-60.

Louter, P.J., Ouwerkerk, C., \& Bakker, B.A. (1991). An inquiry into successful exporting. European Journal of Marketing, 25(6), 7-23.

Medin, H. (2003). Firms' export decisions - fixed trade costs and the size of the export market. Journal of International Economics, 61(1), 225-241. doi:10.1016/S0022-1996(02)00076-4

Melitz, M.J. (2003). The impact of trade on intra-industry reallocations and aggregate industry productivity. Econometrica, 71(6), 1695-1725.

Navarro-García, A., Schmidt, A.C., \& Rey-Moreno, M. (2015). Antecedents and consequences of export entrepreneurship. Journal of Business Research, 68(7), 1532-1538. https://doi.org/10.1016/j.jbusres.2015.01.047

Nemkova, E., Souchon, A. L., \& Hughes, P. (2012). Export decision-making orientation: an exploratory study. International Marketing Review, 29(4), 349-378.

Özler, Ş., Taymaz, E., \& Yılmaz, K. (2009). History matters for the export decision: plant-level evidence from Turkish manufacturing industry. World Development, 37(2), 479-488.

Ramaseshan, B., \& Soutar, G.N. (1996). Combined effects of incentives and barriers on firms' export decisions. International Business Review, 5(1), 53-65.

Shamsuddoha, A.K. (2004). Antecedents of Firm Export Performance: The role of Export Promotion Programs. Australia: Faculty of Business Queensland University of Technology Brisbane.

Sigeze, C., Balli, E., \& Tras, M.F. (2016). The relationship between R\&D and export decision of Turkish firms. 13th International Scientific Conference on Economic and Social Development, Barcelona.

Sood, H.J., \& Adams, P. (1984). Model of management learning style as a predictor of export behavior and performance. Journal of Business Research, 12, 176.

Sousa, J.D., Disdier, A.C., \& Gaigne, C. (2016). Export decision under risk. Cesifo Working Paper, 6134(8), 1-50. 
Sönmez, A., \& Arslan, A.R. (2007). İhracat yapma şekline göre karşılaşılan sorunlar; mobilya endüstrisi örneği. Politeknik Dergisi, 10(4), 403-409.

Statstutor (2016). http://www.statstutor.ac.uk/resources/uploaded/spearmans.pdf

Suarez-Ortega, S.M., \& Alamo-Vera, F.R. (2005). SMEs' internationalization: firms and managerial factors. International Journal of Entrepreneurial Behaviors \& Research, 11(4), 258-279.

Takım, A., \& Ersungur, Ş.M. (2010). Dahilde işleme rejimi: ihracat ve ithalat üzerindeki etkisi. Atatürk Üniversitesi İktisadi ve İdari Bilimler Dergisi, 24(2), 289-305.

Tan, A., Brewer, P., \& Liesch, P. (2018). Rigidity in SME export commencement decisions. International Business Review, 27(1), 46-55.

Thompson, J.L. (1999). A strategic perspective of entrepreneurship. International Journal of Entrepreneurial Behavior and Research, 5(6), 279-296.

Tomiura, E. (2007). Effects of R\&D and networking on the export decision of Japanese firms. Research Policy, 36(5), 758-767.

Türko, E. S., \& Yellice, B. (2016). İhracat yapmak ya da yapmamak... İhracat kararında belirsizliğe tolerans: Bursa'da tekstil endüstrisinde bir uygulama. II. Uluslararası Kafkasya-Orta Asya Dış Ticaret ve Lojistik Kongresi Bildiriler Kitabı, 373-386.

Türko, E. S., \& Yellice, B. (2017). İhracat yapmak ya da yapmamak... İhracat kararında belirsizliğe tolerans: Bursa'da tekstil endüstrisinde bir uygulama. The Journal of Academic Social Sciences, 5(63), 300-314. http://dx.doi.org/10.16992/ASOS.13319

Ward, E.A. (1993). Motivation of expansion plans of entrepreneurs and small business managers. Journal of Small Business Management, January, 32- 38.

Yi, J., \& Wang, C. (2012). The decision to export: firm heterogeneity, sunk costs, and spatial concentration. International Business Review, 21(5) 766-781. https://doi.org/10.1016/j.ibusrev.2011.09.001

Zohari, T. (2008). The Uppsala internationalization model and its limitation in the new era. International Management Stratagy (IMS). Stockholm University School of Business. http://www.digitpro.co.uk/paper/The\%20Uppsala\%20Internationalization\%20Model_web. pdf

Zou, S., \& Stan, S. (1998). The determinants of export performance: a review of the empirical literature between 1987 and 1997. International Marketing Review, 15(5), 333-356. 